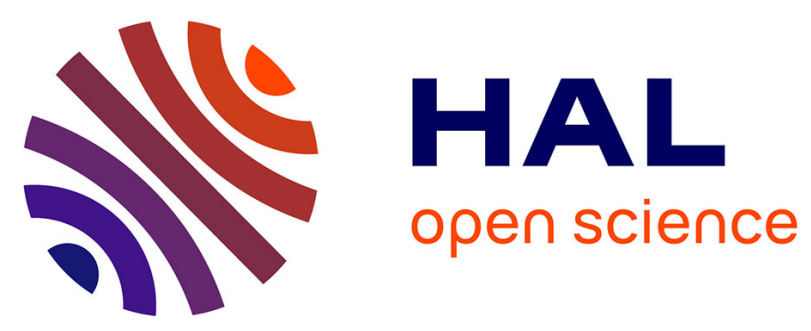

\title{
Decreasing uplift rates and Pleistocene marine terraces settlement in the central lesser Antilles fore-arc (La Desirade Island, 16 degrees N)
}

Jean-Len Leticee, Jean-Jacques Cornee, Philippe Munch, Jan Fietzke, Melody Philippon, Jean-Frederic Lebrun, Lyvane de Min, Auran Randrianasolo

\section{To cite this version:}

Jean-Len Leticee, Jean-Jacques Cornee, Philippe Munch, Jan Fietzke, Melody Philippon, et al.. Decreasing uplift rates and Pleistocene marine terraces settlement in the central lesser Antilles fore-arc (La Desirade Island, 16 degrees N). Quaternary International, 2019, 508, pp.43-59. 10.1016/j.quaint.2018.10.030 . hal-02115445

\section{HAL Id: hal-02115445 \\ https://hal.science/hal-02115445}

Submitted on 22 Oct 2021

HAL is a multi-disciplinary open access archive for the deposit and dissemination of scientific research documents, whether they are published or not. The documents may come from teaching and research institutions in France or abroad, or from public or private research centers.
L'archive ouverte pluridisciplinaire HAL, est destinée au dépôt et à la diffusion de documents scientifiques de niveau recherche, publiés ou non, émanant des établissements d'enseignement et de recherche français ou étrangers, des laboratoires publics ou privés.

\section{(ㅇ)(1) $\$$}

Distributed under a Creative Commons Attribution - NonCommerciall 4.0 International 
Version of Record: https://www.sciencedirect.com/science/article/pii/S1040618218303148

Manuscript_6d1b7cd0ef6d336888548dcbd5c67152

1 Decreasing uplift rates and Pleistocene marine terraces settlement in the central lesser Antilles

2 fore-arc (La Désirade Island, $16^{\circ} \mathrm{N}$ )

3 Jean-Len Léticée, ${ }^{a}$ Jean-Jacques Cornée, ${ }^{a, b^{*}}$, Philippe Münch ${ }^{b}$, Jan Fietzke ${ }^{c}$, Mélodie Philippon ${ }^{a}$, Jean-

$4 \quad$ Frédéric Lebrun ${ }^{a}$, Lyvane De Min ${ }^{\mathrm{a}, \mathrm{b}}$, Auran Randrianasolo ${ }^{\mathrm{a}}$

$5{ }^{a}$ Géosciences Montpellier, Université des Antilles, CNRS, Pointe à Pitre, Guadeloupe, FWI

$6{ }^{b}$ Géosciences Montpellier, Université de Montpellier, CNRS, Montpellier, France

$7{ }^{c}$ GEOMAR, Helmholtz Centre for Ocean Research, Kiel, Wischhofstr, 1-3, 24148 Kiel Germany

8 Corresponding author: jean-jacques.cornee@gm.univ-montp2.fr (J.-J. Cornée)

9

10

11

12

13

14

\section{Abstract}

This study investigates the Lesser Antilles forearc at the latitude of Guadeloupe Archipelago and evidences that La Désirade Island, the eastermost island of the forearc, displays a staircase coastal sequence including four uplifted marine terraces and an upper reefal platform with mean shoreline angle elevations ranging from 10 and $210 \mathrm{~m}$ above sea level (asl). The platform paleobathymetry is constraint by a detailed analysis of the sediments. We propose a revised morphostratigraphy for this coastal sequence including 5 paleo-shorelines based on six U/Th dating from aragonitic corals from the three lowest terraces combined with paleobathymetric analysis of the fossil corals present in the upper platform allow. Terrace and upper platform carving of construction periods occurred during Marine Isotopic Stages MIS 5e, MIS 9, and during the intervals MIS 15-17, MIS 19-25 and MIS 31-49 (upper coral reef platform). Our results evidence a bulk decreasing uplift rate since early Calabrian to Present-Day, clearly documented since $310 \mathrm{ka}$ (MIS 9) (from 0.14-0.19 to ca $0 \mathrm{~mm} / \mathrm{y}$ ). Our data are consistent with first the transient influence of the subducting oceanic Tiburon ridge during Calabrian, then with other parametres of the subduction zone since late Calabrian to Present-Day (dip of the slab, basal erosion of the upper plate, inherited structures...) .

1

(C) 2018 published by Elsevier. This manuscript is made available under the CC BY NC user license https://creativecommons.org/licenses/by-nc/4.0/ 
Keywords: Pleistocene; Lesser Antilles subduction; La Désirade; coral reef terraces; uplift; Tiburon Ridge.

\section{Introduction}

Strain pattern and rates observed in fore-arcs of subduction zones are controlled by subduction dynamics, sediment supply at the trench and structural inheritances affecting the upper plate (Noda, 2016). In particular, vertical motions in fore-arcs can result from several mechanisms such as: (i) varying geodynamical subduction regime (compressional or extensional) (Shemenda, 1994; Lallemand, 1999), (ii) basal tectonic erosion of the upper plate or accretionary processes (von Huene and Culotta, 1989; Lallemand, 1995; Clift and Vanucci, 2004), (iii) subduction of downgoing plate asperities (such as seamounts, spreading ridges or fracture zone ridges ) (e.g. Collot and Fisher,1989; Dominguez et al., 1998, 2000), (iv) or strain partitioning during oblique subduction driving positive or negative flower structures along strike-slip faults (Gutscher et al., 1998; von Huene et al., 2003; Barnes and Nicol, 2004). Thus, the study and quantification of the distribution and wavelenght of vertical tectonic motions through space and time is key to determine long-term subduction dynamics, but also to assess seismic hazards in subduction zones.

Submerged and/emerged sequences of marine terraces are very useful datable paleosea levels markers as they allow for calculating uplift or subsidence rates (e.g. Henry et al., 2014; Pedoja et al., 2011, 2014; Saillard et al., 2009, 2011). Coastal uplift rates since MIS 5e have been found significantly higher in highly coupled subduction zones than in other geodynamic settings (Pedoja et al., 2011; Henry et al., 2014). Moreover, coastal uplift rates in fore-arc settings have been found correlated mainly with the distance to the trench (with decreasing uplift rates landward up to $\sim 300 \mathrm{~km}$ ), the slab dip and the position along the trench (Henry et al., 2014). The tectonic regime of the subduction margin (erosive vs accretionary) and the overriding plate tectonic regime (compressive vs extensive) appear only gently correlated (Henry et al., 2014; Noda, 2016). Noticeably, the convergence velocity, 
subduction obliquity, oceanic crust age, interplate friction force and overriding plate velocity do not appear correlated with coastal uplift rates of fore-arcs (Henry et al., 2014).

The Lesser Antilles subduction is considered as a weakly coupled accretionary subduction zone where an old oceanic lithosphere slowly subducted $(2 \mathrm{~cm} / \mathrm{an})$ beneath the Caribbean plate and with an accretionnary compressional fore-arc basin ((e.g. Von Huene and Scholl, 1991; Clift and Vannucchi, 2004; Noda, 2016). This description corresponds well to the southern Lesser Antilles where an uplifted sequence of marine terraces has been extensively studied in the outer fore-arc, in the Barbados Island (e.g. Taylor and Mann, 1991; Schellmann and Radtke, 2004). However many sequences of marine terraces also occur in the central Lesser Antilles fore-arc, i.e. to the North of the Martinique Island, but have been more scarcely studied (Désirade: Battistini et al., 1986; MarieGalante : Feuillet et al., 2004). North of Martinique, the Lesser Antilles subduction zone has a different tectonic regime from the one at the latitude of the Barbados Island exemplified by a narrowed accretionnary prism, an extensional overriding plate tectonic regime (Feuillet et al., 2002; De min et al., 2014), the subduction of sediments deeper into the subduction zone (Bangs et al., 2003) and the subduction of aseismic ridges (Bouysse and Westercamp, 1988). We detail here the quantification of vertical motion in La Désirade Island, i.e. the easternmost island (185 km west of the trench) island of the fore-arc, since 1.5 Ma. In La Désirade Island, a stair-cased marine terraces sequence has been identified since a long time (Lasserre, 1957; Battistini et al., 1986) and PliocenePleistocene carbonate platform deposits reach 210 m in elevation (Andreïeff et al., 1989; Münch et al., 2013). To reach this goal, we acquired a new sedimentological, geomorphological and radiochronological dataset from uplifted constructed (corals) marine terraces and reefal carbonate platforms. This dataset allows us to calculate mean coastal uplift rates of the fore-arc since $\sim 1.5 \mathrm{Ma}$ and to discuss about the fore-arc tectonic structures responsible for terraces uplift and, at subduction-scale, the mechanical behavior of the subduction interface at $16^{\circ} \mathrm{N}$ latitude in the Caribbean. 


\section{Geodynamic setting}

The Lesser Antilles Arc emplaced at the eastern boundary of the Caribbean Plate as a result of the west-southwestward subduction of North America and South America oceanic lithospheres, at a rate of around $2.0 \mathrm{~cm} / \mathrm{y}$ (e.g. Deng and Sykes, 1995; Dixon et al., 1998; De Mets et al., 2000; Pindell and Kennan, 2009) (Fig. 1). The NW-SE trending Barracuda and Tiburon ridges are the diffuse plate boundary between North and South American plate (Fig. 1). These features accommodate the slow North and South America plate convergence and consist of oceanic fracture zones reactivated since the Middle Miocene, and the Pleistocene respectively (Patriat et al., 2011; Pichot et al., 2012). At La Désirade latitude, the subduction is orthogonal. The ridges trend oblique to the plate motion vector, thus sweeping the subduction zone from North to South at a rate of $2.0 \mathrm{~cm} / \mathrm{y}$. Nowadays, the topographic effect of the Tiburon ridge is observed across the outer fore-arc to the East of La Désirade Island (Figs. 1 and 2) (McCann and Sykes, 1984; Bouysse and Westercamp, 1990; Bangs et al., 2003; De Min et al., 2015). Northwestward of La Désirade, the Lesser Antilles trench curves and extends into the E-W Puerto Rico Trench. Northwardly, increasing subduction obliquity resulting from the trench curvature triggers strain partitioning in the upper plate that induced trench-parallel strike-slip combined with trench-parallel extension in the fore-arc (Bouysse and Westercamp, 1990; Feuillet et al., 2002; 2004; Laurencin et al., 2017; Legendre et al., 2018).

In the Guadeloupe archipelago fore-arc extensive tectonics is highlighted by two main E-W trending grabens: the Marie-Galante graben and the La Désirade graben (Fig. 2). The Marie-Galante graben is bounded to the North by the Basse-Terre Island, corresponding to the active volcanic arc, and by the Grande-Terre Island, corresponding to a tectonic high, and to the South, by the Marie Galante Island corresponding to a tectonic high. La Désirade Island is located on top of the hangingwall of the main southern border normal faults of the La Désirade graben. The La Désirade tectonic high extends to 
the South into the submerged Karukéra spur that is the eastern border of the Marie-Galante basin. The age and characteristics of this extensive tectonics and related fore-arc uplift are debated.

Based on the study of a flight of reef terraces, Feuillet et al. (2004) proposed that, since $330 \mathrm{ka}$, the whole archipelago emerged, underwent a uniform uplift and regional westward tilting by $0.35^{\circ}$. Following these authors, La Désirade, closest island to the trench, should have emerged since $330 \mathrm{ka}$ and then should have been more uplifted than other islands in relation with a westward tilting. Feuillet et al. (2002) interpreted these features as trench-parallel extension linked to slip partitioning along the northern part of the Lesser Antilles subduction zone. Feuillet et al. (2004) suggested that the tilt probably resulted from a transient deformation episode at the subduction interface that predated the late Pleistocene.

Based on the study of Pliocene-Pleistocene carbonate platforms, Cornée et al. (2012) and Münch et al. $(2013,2014)$ evidenced that the emergence of islands of Guadeloupe archipelago occurred in the 1.07-1.54 Ma interval, i.e. 0.74 to $1.21 \mathrm{Ma}$ earlier than proposed by Feuillet et al. (2004). Offshore, De Min et al. (2015) showed that the Karukéra spur experienced three main extensional episodes (i.e. Eocene?-Oligocene, Late Miocene and since Calabrian) with alternations between uplift and subsidence periods. The main extensional directions evolved from NW-SE, E-W to N-S, respectively (De Min et al., 2015). Since Calabrian, the Karukéra spur tilted to the east-northeast triggering subsidence of the Eastern Flank (more than $2000 \mathrm{~m}$ ) and emersion of both the northern part up to La Désirade and the western flank of the spur (De Min et al., 2015).

\section{Geomorphology and geological setting}

La Désirade Island is $11.5 \mathrm{~km}$ long, $2 \mathrm{~km}$ large and reaches a maximum altitude of $276 \mathrm{~m}$ above sea level (asl). The island consists of Jurassic to Cretaceous metamorphic basement capped by ca $120 \mathrm{~m}$ thick Pliocene-Pleistocene carbonate platform deposits (e.g. Westercamp, 1980; Léticée, 2008; 
Lardeaux et al., 2013; Münch et al., 2013; 2014). These carbonate platform deposits span the Zanclean-Calabrian interval (Léticée, 2008; Münch et al., 2013, 2014). The youngest deposits of this platform (1.54-1.07 Ma interval; Münch et al., 2014) correspond to a thick-branched Acropora palmata reef platform reaching a 10 to $15 \mathrm{~m}$ thickness at maximum (Fig. 4). These deposits occur near sea-level at Anse des Galets, Beauséjour at the western tip of the island, and at an elevation of 210 meters asl at the top of the eastern part of the island. These differences in elevation were triggered by a major episode of extensional tectonics accommodated by both $\mathrm{N} 90^{\circ} \mathrm{E}$ and $\mathrm{N} 110^{\circ} \mathrm{E}-$ $\mathrm{N} 130^{\circ} \mathrm{E}$ normal faults, either during Ionian (Feuillet et al., 2004) or during Early Calabrian (Münch et al., 2014). This episode caused the emergence of Pliocene-Pleistocene carbonate platforms that now form the Upper Plateaus, and their local tilting (Lardeaux et al., 2013; Münch et al., 2014).

At La Désirade the amplitude of the tides is less than a meter $(30 \mathrm{~cm}$ with a maximum from 50 to 60 cm) (e.g. BRGM, 2010). The northern coast of La Désirade is dominated by erosion and high and steep cliffs with few preserved raised beaches and coral reef terraces. On the southern coast of the Mahault (Fig. 3A), Battistini et al. (1986) provided an age of $272+72$ to $-43 \mathrm{ka}$. Plateaus, are fringed by up to four mid-late Pleistocene coral reef terraces or wavecut surfaces, which were identified at Grande Terre and Marie Galante (de Reynal de Saint Michel, 1966; Westercamp, 1980; Battistini et al., 1986; Feuillet et al., 2004) (Fig. 2). In these islands, the lowermost terrace, at an elevation of 5-10 m asl, was dated from the $158-110$ ka interval (Last 
Interglacial Maximum terrace; Battistini et al., 1986; Feuillet et al., 2004). At Marie Galante, a second

148 uplifted marine terrace, occurring at an altitude ranging from 50 to $108 \mathrm{~m}$ asl, yielded a model age of

149249 ka (terrace T2; Villemant and Feuillet, 2003; Feuillet et al, 2004). By correlating measured ages of

150 both marine terraces in Marie Galante with the SPECMAP isotopic curve, Feuillet et al. (2004)

151 proposed an age of $330 \mathrm{ka}$ for the emersion of all islands of the archipelago.

152 We investigated La Désirade Island for datable uplifted marine erosional terraces (wavecut surfaces), 153 marine constructional terraces (coral reef) and depositional terraces (beaches) to analyse Pleistocene 154 vertical tectonic motions of the fore-arc.

\section{Methods}

\subsection{High-resolution mapping}

We conducted several field-mapping campaigns at 1/10000 scale, mapping with in detail wavecut surfaces and marine terraces. Elevations and spatial extent of the terraces were determined using field mapping, Garmin GPS and a 5m resolution DEM (Litto-3D Guadeloupe, V1, IGN-SHOM 2013). Cross-sections were built using QGIS software (http://www.qgis.org) (Fig. 5). Elevation data are from SHOM and function of the Present-Day mean sea level reference (uncertainty is $\pm 1 \mathrm{~m}$ ). Special attention was devoted to the location of fossil strandlines, flat and subhorizontal terraces, beach facies, notches, coral reefs, and shoreline angle (Lajoie, 1986; Pirazzoli et al., 1993; Montaggioni and Braithwaite, 2009; Pedoja et al., 2011; Jara-Muñoz et al., 2015) (Fig. 5D). For the coral reef platform its emergence. 
We made sure that the necessary conditions for using U-series ages of corals were meet by our samples: (i) few or no evidence of recrystallization, (ii) presence of little or no non-radiogenic ${ }^{230} \mathrm{Th}$ and (iii) initial ${ }^{234} \mathrm{U} /{ }^{238} \mathrm{U}$ value in agreement with modern seawater one (1.141 to 1.155; Delanghe et

172 al., 2002). Corals selected for U/Th datations were first examined in thin-sections in order to select 173 aragonite samples and avoid recrystallization or pore-infilling. We determine their mineralogy and 174 quantify their aragonitic content by X-Ray diffraction at the University of Montpellier (Philips X'Pert 175 PRO MPD diffractometer; PANalytical X'Pert HighScore Plus version 3.0.5 software). Each sample was analyzed during one hour between 5 and $60^{\circ}$ Theta, with a $0.033^{\circ}$ Theta step. We selected six samples that fulfil conditions and yield more than $95 \%$ of aragonite.

We carried out radiometric U/Th dating using the "AXIOM“ MC-ICP-MS at IFM-GEOMAR Kiel, Germany. About $60 \mathrm{mg}$ of carbonate powder drilled from each sample were dissolved $\left(\mathrm{HNO}_{3}\right)$, and 50 $\mu$ of a pre-mixed ${ }^{229} \mathrm{Th} /{ }^{233} \mathrm{U} /{ }^{236} \mathrm{U}$-spike solution (“Mix9”) were added before evaporating the samples on hotplates at $90^{\circ} \mathrm{C}$ under filtered air. Dried samples were dissolved in $7 \mathrm{n} \mathrm{HNO}_{3}$ and passed through ion chromatographic columns containing $2 \mathrm{ml}$ of EICHROM's UTEVA resin. After separation, two fractions ( $U$ and Th) were measured separately using the MIC (Multi-lon-Counting) method described by Fietzke et al. (2005). We controled the analytical quality by analyzing the reference standard (HU 1) and two blank samples. Secular-equilibrium standard $\mathrm{HU}-1$ gained the ${ }^{230} \mathrm{Th} /{ }^{234} \mathrm{U}=0.9989 \pm 0.0014$ and ${ }^{234} \mathrm{U} /{ }^{238} \mathrm{U}=0.9994 \pm 0.0011$ activity ratios (95\% confidence). Within the limits of uncertainty both isotope ratios match the reference values of 1 . Analytical blanks are provided in Table 1 . Being typically about 3-4 orders of magnitude lower than the respective sample amounts analytical blanks were practically insignificant but nevertheless data were blank-corrected. We corrected from the non-radiogenic ${ }^{230}$ Th incorporated during carbonate formation using the following equation:

${ }^{230} \mathrm{Th}_{\mathrm{xs}}={ }^{230} \mathrm{Th}_{\text {measured }}-{ }^{230} \mathrm{Th}_{\text {non-rad }}={ }^{230} \mathrm{Th}_{\text {measured }}-(0.7 \pm 0.2) *{ }^{232} \mathrm{Th}_{\text {measured }}$

192 Where ${ }^{230} \mathrm{Th}_{\mathrm{xs}}$ represents the excess amount of ${ }^{230} \mathrm{Th}$ produced by the decay of uranium.

\subsection{Uplift rate determination}


We assigned a sea-level highstand corresponding to a Marine Isoltopic Stage to each dated paleoshoreline. Even if large uncertainties remain in estimating paleo-sea level during Pleistocene, we use the long record of paleo-sea levels from Rohling et al. (2014) because it has been validated from two independent methods: (i) deep-sea temperature changes from oxygen isotopes converted into sea level and (ii) hydraulic control of water exchange through a narrow connection with the open ocean in semi enclosed seas (Red Sea and Mediterranean). We give the paleo-sea levels with a wide error margins for each isotopic stage, graphically calculated from the curve of Rohling et al. (2014). Ages of the different interglacial MIS, even if sometimes debated, are the mean ages provided by these authors. Results do not take into account isostatic correction. We estimate relative vertical uplift between each paleoshoreline on the basis of the difference of elevations corrected from paleo-sea levels of Rohling et al. (2014), and the morphostratigraphic model of Lajoie (1986) and Saillard et al. (2009). This stratigraphic model has the following equation: Uplift rate interval $_{T n / T n+1}=\left[\left(\right.\right.$ elevation of shoreline angle of Terrace $_{n}-$ elevation of shoreline angle Terrace $\left._{n+1}\right)-$ equation allows us to propose apparent uplift rates between the formations of two successive shoreline angles related to marine terraces.

\subsection{Acropora palmata reef platform (top of Upper Plateaus)}

The platform was uplifted at maximum to an elevation of $210 \mathrm{~m}$ asl and displays in growth position massive coral colonies and locally thick-branched Acropora palmata colonies (Fig. 4C) and packstones dominated by bivalves and benthic foraminifers (among which Amphisteginids). The general sedimentological features of this unit are indicative of an inner reefal platform depositional environment at very shallow water (Montaggioni and Braithwaite, 2009). Especially, the Caribbean species A. palmata optimally lives between sea level and $5 \mathrm{~m}$ bsl (Veron, 2000) (Fig. 4D). Thus, we 
considered in our calculations that the last unit of the Pliocene-Pleistocene carbonate platform was

220 deposited at ca $5 \mathrm{~m}$ below sea level (bsl).

\subsection{Depositional marine Terrace 1}

222 Terrace 1 was found in the northeastern part of the island as a $500 \mathrm{~m}$ wide subhorizontal erosional

223 relict between Pointe Adrien and Pointe du Grand Abaque. The metamorphic basement and the red 224 algal platform deposits are uncomformably oeverlaid by terrace 1 between 90 and 85 m asl (Fig. 3A

225 and 6A), corresponding to the $90 \mathrm{~m}$ asl littoral terrace of Lasserre (1961). Above the basement, 226 locally few dm-thick littoral limestones with pebbles are preserved, sometimes encrusted by red 227 algae (Fig. 6B) or bored by lithophagid molluscs. These pebbles are derived from both the metamorphic basement and the Zanclean red algal carbonate platform. Limestones are packstones with coral and oyster fragments, Amphisteginids, regular echinoids and red algae. Discrete notches are locally preserved, carved into the Zanclean red algal carbonate platform deposits (Figs. 3A and $5 \mathrm{~A})$, and the shoreline angle is located at $90 \pm 1 \mathrm{~m}$ asl. These deposits are indicative of a very shallow littoral environment and were erroneously mapped as basal deposits of the Zanclean platform by Westercamp (1980).

\subsection{Depositional marine Terrace 2}

The summit of the deposits of Terrace 2 correspond to foreshore deposits or coral buildups at $76 \pm 1$ $\mathrm{m}$ asl. These are only found in the eastern part of the island, along $4 \mathrm{~km}$ between Pointe Adrien and Baie Mahault (Figs 3, 5 and 7A), corresponding to the $75 \mathrm{~m}$ asl littoral terrace of Lasserre (1961). At Route de la Montagne, a well preserved 5 m thick marine terrace rests directly on the metamorphic basement and its top is at $76 \pm 1 \mathrm{~m}$ asl (Fig. $3 \mathrm{~A}$ and $7 \mathrm{~B}$ to $\mathrm{E}$ ). From base to top, it contains: loose

241 pebbles, normally graded conglomerates with pebbles originating from the basement and the

242 Zanclean red algal platform, calcareous conglomerates bearing Amphisteginids and bioclastic 243 limestones with low-angle planar bedding are found in the uppermost part. These latter are 
packstones to grainstones with benthic foraminifers (among which Amphisteginids), red algae,

245 gastropods, bryozoans, corals and echinoids. Some coral fragments are coated with encrusting red 246 algae (rhodoliths). Aragonitic Diploria coral colonies from the uppermost part of the deposits (Fig. 7E

247 to G) yielded an age older than 500 ka (Sample DS 10-05; Table 2). Based only on the uranium

248 isotope ratio it is possible to calculate a U/U apparent age of $659-33 \mathrm{ka},+36 \mathrm{ka}$ assuming an initial ${ }^{234} \mathrm{U} /{ }^{238} \mathrm{U}$ activity ratio of 1.146 (modern sea water).

250

251

252

253

254

255

256

257

258

259

260

261

262

263

264

All these deposits are indicative of a reefal to peri-reefal depositional environment in foreshore to uppermost shoreface setting (Tucker and Wright, 1990; Montaggioni and Braithwaite, 2009). They were deposited at the foot of a paleocliff transecting the Zanclean platform and the metamorphic basement. The summit of this depositional terrace, at $76 \pm 1 \mathrm{~m}$ asl, is considered as a shoreline angle level. These deposits were erroneously mapped as basal deposits of the Zanclean platform (Westercamp, 1980).

\subsection{Depositional marine Terrace 3}

A subhorizontal wavecut surface is scarcely preserved $36 \mathrm{~m}$ asl all around the island (Figs. 3 and 5 ). This surface corresponds to the $35 \mathrm{~m}$ asl terrace identified at the eastern tip of the island by Lasserre (1961). This wavecut surface is found transecting either the Zanclean red algal platform at Cap Frégule or the basement at Roche du large (Fig. 8D).

At Pointe Doublé, a depositional marine terrace was also identified (Lasserre, 1961). This terrace is topped by a flat surface at $36 \pm 1 \mathrm{~m}$ asl and consists of $2.5 \mathrm{~m}$ thick karstified grainstones with planar laminations (Fig. 8C) that yielded rounded fragments of red algae, mollusks, Amphisteginids and few basement clasts. These deposits are considered as deposited in foreshore setting and their summit is interpreted as representing a shoreline angle.

At Cul Foncé, we evidenced a depositional marine terrace made of conglomerates and limestones and topped by a flat surface culminating at $36 \pm 1 \mathrm{~m}$ asl surface (Fig. 8A and B). This terrace rest 
against a cliff in the basement between 28 and $36 \mathrm{~m}$ asl above an erosion surface (Fig. 9A). In its lower part, occur conglomerates with cross-trough stratifications and planar bedding (Fig 9C). Pebbles are composed of diverse rocks that originate from both the basement and the Zanclean platform. Above, conglomerates evolve into bioclastic limestones with 3D dunes (Fig. 9B), low-angle parallel laminations (Fig. 9C and E), cross-stratifications (Fig. D) and locally hummocky crossstratifications. Some broken massive coral colonies can be found (Fig. 9E, F).

These sediments were deposited into perireefal high energy depositional environment oscillating between foreshore and upper shoreface setting at the foot of a paleocliff (Fig. 8B). The summit of the foreshore deposits at $36 \mathrm{~m} \pm 1$ asl corresponds to the shoreline angle, and notches in the basement can be found at this elevation. The aragonitic coral sample DS10-40 yielded a U/Th age of $306 \pm 6$ ka, (Fig. 9, E and F; Table 2). These deposits were erroneously mapped as Zanclean carbonate platform deposits (Westercamp, 1980).

\subsection{Coral reef Terrace 4}

Coral reefs of Terrace 4 are well preserved and were previously identified (Lasserre, 1961; Battistini et al., 1986; Feuillet et al., 2004). This constructed terrace can be followed at an elevation between sea level (distal edge) and $+10 \mathrm{~m}$ asl (inner edge). The paleo-shoreline angle of this terrace was patchily reconstructed all around the island based on scattered but abundant exposure at $10 \mathrm{~m}$ asl: between Baie Mahault and Le Souffleur (Fig. 4A), Cul Foncé (Fig. 8A), Cap Frégule (Fig. 10), Airport quarry, Pointe Fromager (Fig. 11) and Pointe Mancenillier (Fig. 12F). We detail here only the locations where we were able to perform U/Th datings.

At Baie Mahault (Fig. 12A) massive to columnar corals, mainly Montastraea (Fig. 12A and E) associated with Diploria and Porites, are cropping out landwards whereas A. palmata boundstones and Strombus accumulations are abundant seawards (Fig. 12, A, D, E). The summit of the deposits is gently dipping $\left(0.5\right.$ to $\left.1^{\circ}\right)$ seawards from $10 \mathrm{~m}$ to $4 \mathrm{~m}$ asl. At the top of the preserved reef deposits is a tens of cm-thick level displaying thin-branched Acropora at $5 \mathrm{~m}$ asl (Fig. 12A and B). These corals 
yielded an age at $133.5 \pm 0.84$ ka (Sample DS 11-43, Fig.12A to C; Tab. 2). This age is much younger

294 and precise than the one previously published, i.e. $272+72$ to -43 ka (Battistini et al., 1986), and we

295 considered that our new age as the estimate for Terrace 4. The Terrace T4 corresponds to a fringing

296 reef complex in high-energy shallow-water environments, deposited on a seaward low-angle dipping

297 ramp.

In the southwestern part of the island the reef complex comprises large colonies of A. palmata, Montastraea and Diploria in growth position and coral rubbles and coarse-grained bioclastic limestone with Strombus. This complex gently dips to the West, from $10 \mathrm{~m}$ asl at Airport Quarry to sea level at Cap Frégule and Pointe Colibri. We performed U/Th dating at $2.5 \mathrm{~m}$ asl at Pointe Frégule

(Fig. 10F and G). Two aragonitic coral colonies, A. palmata (DS 10-12a) and Montastraea sp. (DS1012b) provided ages, $126.09 \pm 0.58 \mathrm{ka}$ and $128.19 \pm 0.61$, respectively (Fig. 3 and Table 2). These results are in good agreement with the age we obtained for the Terrace 4 in Baie Mahault and with those previously obtained at Pointe Colibri (Battistini et al., 1986; Feuillet et al., 2004).

\section{Discussion}

\subsection{Ages used for the uplift rates calculation}

Some uncertainties remain concerning the ages of terraces 1 and 2. However, we proposed here estimate based on the $\mathrm{U} / \mathrm{Th}$ ages of terraces 3 and 4 and the estimated age of the A. palmata coral platform. We correlated each terrace with the paleo-sea level curve from Rohling et al. (2014) and one or several Marine Isotopic Stage highstand (Fig. 13).

Terrace 4 yielded ages ranging between 126-133 ka, indicating that the $10 \mathrm{~m}$ asl paleoshoreline formed during the the Last Interglacial Maximum highstand (MIS 5e) dated at 122 ka. Terrace 3 yielded an age of $305.76 \pm 5.96 \mathrm{ka}$, indicating that the shoreline angle at $36 \pm 1 \mathrm{~m}$ asl formed during the 310 ka MIS 9 highstand. Terrace 2 yielded an age of $659-33 \mathrm{ka},+36 \mathrm{ka}$, indicating that the 
MIS 17 one at $700 \mathrm{ka}$. In Grande Terre, the A. palmata reef platform deposited during the reverse subchron C2r, in the 1.07-1.54 Ma interval (Münch et al., 2014). This platform deposited synchronously in La Désirade and in Marie Galante (Cornée et al., 2012; Münch et al., 2013, 2014). This interval includes two main highstands: MIS 31 at $1.07 \mathrm{Ma}$ and MIS 47 at $1.48 \mathrm{Ma}$ (Fig. 13).

As a consequence, the age of Terrace 1 is bracketed by the estimated ages range for Terrace 2 , correlated with MIS 15 or MIS 17 highstands, and the age range of $A$. palmata reef platform (MIS 3147 interval). Consequently, we considered that Terrace 1 was formed in a time span ranging from the high sea-levels MIS 19 to 25 , i.e. in the 780 to 970 ka taking into account the youngest age (1.07 Ma) for the A. palmata reef platform (Fig. 13). However the incertitude on the age of the Terrace 1 could be much greater taking into account an older age for the $A$. palmata reef platform.

\subsection{Pleistocene vertical motions in the northern Lesser Antilles fore-arc}

In the Guadeloupe Archipelago, apart from La Désirade, uplifted Pleistocene marine terraces also crop out in Grande Terre and Marie Galante. In Grande Terre, only the Last Interglacial Maximum terrace was recognized at an elevation between 0.5 and $6 \mathrm{~m}$ asl and was dated between 149 and 158 ka (Battistini et al., 1986; Feuillet et al., 2004) (Fig. 14). In Marie Galante, a flight of four uplifted Pleistocene marine terraces was described but only the lowermost one, at an elevation between 2 and $15 \mathrm{~m}$ asl, was dated accurately between between 110 and 134 ka (Battistini et al., 1986; Feuillet et al., 2004). A modeled age at $249 \pm 8$ ka was also proposed for a second terrace on Marie Galante that is the second most elevated at 50-108 $\mathrm{m}$ asl (T2 in Feuillet et al., 2004). This age was calculated in an open system to account for selective mobilities of U-series isotopes in a partly recrystallized (calcite) coral sample (Villemant and Feuillet, 2003). Uplifts are related to a westward tilting and/or local deformation along normal faults bounding the Marie Galante graben. Local deformations result in a lowering of the terraces elevation towards the center of the graben whereas westward tilting of the Marie Galante Island results in higher uplift in the eastern part of the island. In Marie Galante, an uplift rate was calculated for the Last Interglacial Maximum terrace at $0.08 \mathrm{~mm} / \mathrm{yr}$ (Feuillet et al., 
2004). The same authors also calculated higher uplift rates $(0.2 \mathrm{~mm} / \mathrm{yr})$ taking into account an age of 330 ka for the A. palmata reef platform (Upper Plateaus) based on the correlation of both dated terraces with the SPECMAP curve. However, the reverse magnetic polarity of the A. palmata reef platform (Münch et al., 2014) contradicts the estimated age used for uplift rate calculations and questions the validity of the modeled age of Villemant and Feuillet (2003) for the second most elevated terrace in Marie Galante. As we found an age of $659-33 \mathrm{ka},+36 \mathrm{ka}$ for T2 (the second most elevated terrace) and $306 \pm 6$ ka for T3 in La Désirade, the age of the A. palmata reef platform is definitely not $330 \mathrm{ka}$. Thus, only the mean uplift rate of $0.08 \mathrm{~mm} / \mathrm{yr}$ for the MIS 5 terrace in Marie Galante can be considered valid.

In Saint Martin, only the MIS 5 terrace was described and crops out at ca $12 \mathrm{~m}$ asl and, in Puerto Rico, the MIS 5 terrace is between 4.5 and $5.5 \mathrm{~m}$ asl (synthesis in Pedoja et al., 2014) (Fig. 1). In the Dominican Republic, the MIS 5e terrace is between 10 and $20 \mathrm{~m}$ asl (Diaz de Neira et al., 2015).Thus, the uplift of the MIS 5 terrace appears to be limited in the northern Lesser Antilles fore-arc whereas it reaches ca $60 \mathrm{~m}$ asl in the southern Lesser Antilles forearc, in the Barbados Island, where the highest MIS 11 shoreline angle was found between 120 and $140 \mathrm{~m}$ asl (Speed and Cheng, 2004). This highlights the specificity of La Désirade, one of easternmost islands of the fore-arc, where can be depicted vertical motions and deformations of the fore-arc since $1.5 \mathrm{Ma}$.

\subsection{Uplift rates at La Désirade}

\subsubsection{Post -Terrace 4 uplift}

During MIS 5e the sea level was estimated at 2 to $8 \mathrm{~m}$ asl (Kopp et al., 2009; Murray-Wallace and Woodroffe, 2014; Rohling et al., 2014; Creveling et al., 2015) and the paleo-shoreline is presently at $10 \mathrm{~m} \pm 1$ asl. Thus, Terrace 4 experienced $2 \pm 1$ to $8 \pm 1 \mathrm{~m}$ uplift since 122 ka taking into account uncertainties on paleo-sea level during MIS 5e (Fig.13A). Apparent uplift rates range from 0.008 to $0.07 \mathrm{~mm} / \mathrm{y}$. Such rates are very low, especially for an active tectonic setting (Sieh, 1999; Henry et al., 2014; Saillard et al., 2017). As the estimated paleo-shoreline angle from the top of Terrace 4 remains 
at the same elevation around the island, the island underwent a uniform and very slow uplift after MIS 5e without any significant tilting.

\subsubsection{Uplift between Terrace 3 and Terrace 4}

The paleo-shoreline angle of the MIS 9 deposits is at $36 \pm 1 \mathrm{~m}$ asl and dates $310 \mathrm{ka}$. At this time, the high sea level was estimated between 0 and $6 \mathrm{~m}$ asl (Rohling et al., 2014) (Fig. 13). The difference in elevation between MIS 5e and MIS 9 high sea levels is 2 to $8 \mathrm{~m}$. As a consequence, the MIS 9 paleosea level underwent $28 \pm 1$ to $34 \pm 1 \mathrm{~m}$ ( $27 \mathrm{~m}$ at minimum to $35 \mathrm{~m}$ at maximum) uplift before the formation of the MIS 5e coral reef at $122 \mathrm{ka}$. This uplift occurred during a time span lasting $188 \mathrm{ka}$, indicative of apparent uplift rate ranging from 0.14 to $0.19 \mathrm{~mm} / \mathrm{y}$. Even if low, this rate is much greater than the post MIS 5e rate. The mean uplift rate of Terrace 3 in reference to the Present-Day sea level ( $36 \pm 1$ minus 0 to $6 \mathrm{~m}$ during $310 \mathrm{ka}$ ) is in the interval 0.11 to $0.14 \mathrm{~mm} / \mathrm{y}$. It is to note that the Terrace 3 is scarcely preserved but found all around the island at the same elevation, thus indicating the lack of tilting since $310 \mathrm{ka}$.

\subsubsection{Uplift between Terrace 2 and Terrace 3}

The shoreline angle of Terrace 2 is at $76 \pm 1 \mathrm{~m}$ asl. During MIS 15 to 17 the high sea levels were estimated to be $10 \mathrm{~m}$ bsl to $22 \mathrm{~m}$ asl (Rohling et al., 2014). The difference in elevation between Terraces 2 and 3 is $40 \pm 1 \mathrm{~m}$. The uplift between MIS $15-17$ and MIS 9 is thus in the $18 \pm 1$ to $50 \pm 1 \mathrm{~m}$ interval in a time range of $310 \mathrm{ka}$ minimum to $390 \mathrm{ka}$ maximum. The apparent uplift rate is thus estimated in the $0.04-0.16 \mathrm{~mm} / \mathrm{y}$ interval. The mean uplift rate of Terrace 2 in reference to the Present-Day sea level ranges between 0.14 and $0.28 \mathrm{~mm} / \mathrm{y}$.

\subsubsection{Uplift between Terrace 1 and Terrace 2}

The shoreline angle of Terrace 1 is at $90 \pm 1 \mathrm{~m}$ asl and may correspond to MIS 19 or 21 or 25 high sea levels. The lowest and highest elevation of sea level for this time interval are estimated $5 \mathrm{~m}$ bsl and 19 asl, respectively (Rohling et al., 2014) (Fig. 13). The difference in elevation between terraces 1 and 
2 is $14 \pm 1 \mathrm{~m}$. The extreme net values of uplift and subsidence are thus +19 to $-7 \mathrm{~m}$, respectively. The time range of the uplift lasted from MIS 17 to MIS 25 at maximum ( $270 \mathrm{ka}$ ), from MIS 17 to MIS 19 at minimum $(80 \mathrm{ka})$. We estimate that the vertical motion rate is ranging between ca 0 and +0.24 $\mathrm{mm} / \mathrm{y}$. The mean uplift rate of Terrace 1 in reference to the Present-Day sea level (90 $\mathrm{m}$ elevation minus $19 \mathrm{~m}$ or plus $5 \mathrm{~m}$ paleosea level during $80 \mathrm{ka}$ minimum and 270 ka maximum) is in the interval 0.26 to $1.2 \mathrm{~mm} / \mathrm{y}$.

\subsubsection{Mean uplift rate of the A. palmata reef platform}

We calculate only mean uplift rate in reference to the Present-Day sea level for the A. Palmata reef platform because of large uncertainties on its age and the age of Terrace 1. In the northeastern part of the island, east of the Coulée du Grand Nord Fault and east of Le Souffleur Fault, the summit of the coral platform crops out at $210 \mathrm{~m}$ asl at maximum (Fig. 3). In the western part of the island, the platform was lowered later by the activity of main $\mathrm{N} 40^{\circ}$ and $\mathrm{N} 130^{\circ}$ trending normal faults. The occurrence of large colonies of $A$. palmata in growth position is indicating a paleobathymetry of $5 \mathrm{~m}$ at the end of deposition (Fig. 4). The minimum and maximum ages of the coral platform are those of the highest sea level MIS 31 (1.07 Ma) and MIS 47 (1.48 Ma), respectively. During MIS 31 and MIS 47 sea level was estimated between 5 to $47 \mathrm{~m}$ asl (Rohling et al., 2014). The mean apparent uplift rate of the coral platform in reference to the Present-Day sea level is in the range of $0.84-2.00 \mathrm{~mm} / \mathrm{y}$.

\subsubsection{Global trend of apparent uplifts at La Désirade}

The mean uplift rates at La Désirade, calculated in reference to the Present-Day sea level, are decreasing since the A. palmata reef platform emergence (Fig. 13). Large uncertainties on the age of the platform and the Terrace 1 do not allow precise comparison. However, the large difference in uplift amplitude between the platform and Terrace 1 suggests that a severe slowing occurred after the emergence of the platform. This is also suggested if only minimum uplift rate values are taken into account. During the period corresponding to the terraces deposition and uplift, mean uplift rates continued to decrease from $0.26-1.19 \mathrm{~mm} / \mathrm{y}$ since the MIS $19-25$ interval to $0.008-0.07 \mathrm{~mm} / \mathrm{y}$ since 
MIS 5e. This decrease is confirmed since Terrace 2 deposition, from $0.14-0.28 \mathrm{~mm} / \mathrm{y}$ to $0.008-0.07$

$417 \mathrm{~mm} / \mathrm{y}$ to Present-Day. Thus, La Désirade was uplifted since the A. palmata reef platform deposition, 418 and uplift decreased at last since 310 ka to become negligible since 122 ka but we favour a major 419 decrease in uplift rates after the platform emersion.

\subsubsection{Pleistocene fore-arc tectonics}

The Pleistocene to Present-Day fore-arc tectonics at the latitude of the Guadeloupe has been described mainly as submeridian extension accommodated by E-W normal faults (Feuillet et al., 2004). This extensional tectonics has been considered coeval with a local west- southwestward tilting of Marie Galante Island. On La Désirade and offshore, on the Karukéra spur (SE of La Désirade), a north-northeast direction of extension, oblique to the fore-arc trend, reactivates the inherited $\mathrm{N} 180^{\circ}$ to $\mathrm{N} 130^{\circ}$ and $\mathrm{N} 70^{\circ}$ to $\mathrm{N} 50^{\circ}$ trending faults and is accommodated by the development of $\mathrm{N} 90^{\circ}$ trending ones in the central part of the spur (Corsini et al., 2011; Lardeaux et al., 2013; Münch et al., 2014; De Min et al., 2015). It is to note that the fore-arc basement, which is cropping out in La Desirade only, is strongly deformed and its structure results from $140 \mathrm{Ma}$ of geological evolution of the Caribbean plate (Lardeaux et al., 2013). De Min et al. (2015) also showed that $1 /$ a differential subsidence of the Karukéra spur occured since the Oligocene, and went on during the Pleistocene, in relation with the activity of the major $N 70^{\circ}$ normal fault, north of La Désirade, and $2 /$ a major eastward or trenchward tilting affected the Karukéra spur during the Pleistocene. This tilting (Fig. 15) was evidenced by differential erosion of Late Pliocene/Early Pleistocene drowned coral reefs which were severely eroded on the northern and western parts of the spur and preserved on the eastern flank (De Min et al., 2015). This tilting is synchronous with the reactivation of $\mathrm{N} 130^{\circ} \mathrm{E}$-striking normal faults on the spur (De Min et al., 2015). In La Désirade, we found that the A. palmata reef platform is mainly preserved in the easternmost part of the island, i.e. in the hanging wall of La Coulée du Grand Nord $\mathrm{N} 130^{\circ}$ E-striking normal fault. In the western part of this compartment, uppermost units of the 
441 platform poorly crop out and the A. Palmata reef platform is only locally preserved in the hanging

442 walls of $\mathrm{N} 40^{\circ} \mathrm{E}$-striking normal faults and is eroded elsewhere. Thus, the distribution of the preserved

443 parts of the A. palmata reef platform is interpreted as indicative of an early Pleistocene eastward tilt

444 coeval with the one observed offshore on the Karukéra Spur and with an extensional tectonic

445 episode.

We evidenced that Terrace 3 and 4 on La Désirade occur at constant elevation all around the island

(Figs. 3,5 and 14 ), indicating that the activity of the $\mathrm{N} 130^{\circ} \mathrm{E}$ and $\mathrm{N} 70^{\circ} \mathrm{E}$ fault systems, crosscutting the island and responsible for a large offset of the A. palmata reef platform, occurred prior to T3 deposition (310 ka). As Terraces 1 and 2 were identified only in the northeastern part of the island, it is difficult to say whether they were affected by fault activity. However, insofar Terraces 1 and 2 remain at rather constant elevation along several kilometers they do not look affected by the observed brittle deformation and tilting of the A. palmata reef platform (Fig. 14). Moreover, the mean uplift rates decreased severely after the uplift of the A. palmata reef platform. Thus, we propose that the $\mathrm{N} 70^{\circ}$ and $\mathrm{N} 130^{\circ} \mathrm{E}$-striking normal fault activity and eastward tilting, coeval with the uplift of the A. palmata reef platform, ceased mainly before Terrace 1 deposition (0.78-0.97 Ma) and after the platform (1.07-1.54 Ma) deposition, i.e. during the Emilian-Sicilian interval.

The last Interglacial Maximum terrace (Terrace 4 in La Désirade) is affected by $\mathrm{N} 90^{\circ} \mathrm{E}$ and inherited $\mathrm{N} 130^{\circ}$-striking normal faults mainly in the innermost part of the fore-arc, on Marie Galante and Grande Terre, but also in the central-western part of the Karukéra spur. Onshore, this terrace is lowered by recent (e.g. the Barre de l'île fault system in Marie Galante) and active (e.g. Gosier fault in southern Grande Terre) faults toward the center of Marie Galante and Grippon plain grabens (Fig. 15, D). However, it remains at $+5 \mathrm{~m}$ asl in eastern and northern Grande Terre, thus indicating the lack of post MIS 5 faulting and tilting in these areas.

At the scale of the archipelago, the organization of marine terraces is different along the coasts of 465 different islands and thus cannot result of a single regional process. We rather evidenced two major 
deformation episodes during the last 1.5 Ma. A first one occurred after the $A$. palmata reef platform

467

and before the Terrace 1 deposition (Emilian-Sicilian interval) (Fig. 15, A and B), characterized in the eastern part of the archipelago by a trenchward tilting and localized uplift in relation mainly with the reactivation of $\mathrm{N} 130^{\circ} \mathrm{E}$ inherited structures during a submeridian extensional episode. The second event started since $0.78-0.97 \mathrm{Ma}$ and is still active_(Fig. $15 \mathrm{C}$ and $\mathrm{D}$ ), and is characterized by the formation of E-W normal faults and the reactivation of $\mathrm{N} 130^{\circ}$-striking normal faults, by differential uplift of Pleistocene marine terraces and by a southwestward tilting of the Marie Galante island.

\subsubsection{Geodynamic implications}

Over the last $5 \mathrm{My}$, the $2 \mathrm{~km}$ high oblique-to-the-trench Tiburon ridge was subducted from North to South along the Lesser Antilles trench (Bangs et al., 2003; Patriat et al., 2011; Pichot et al., 2012). This ridge corresponds to the western end of the North America-South America diffuse plate boundary and its topography has been built in the middle-late Miocene-early Pleistocene (Patriat et al., 2011; Pichot et al., 2012). During the 1.5-1 Ma interval, it was located below the northern tip of the Karukéra spur, $25 \mathrm{~km}$ east of La Désirade (Fig. 15B). La Désirade is the easternmost emerged promontory of the inner fore-arc extending southeastwards to the immerged Karukéra spur (Fig. 2) that recorded a long-term regional extensional tectonics affecting the pre-structured fore-arc basement and cover and reactivating structural Mesozoic inheritance (Lardeaux et al., 2013; De Min et al., 2015). Along the Peru-Chile subduction zone, long-term permanent coastal uplifts coincide with areas of aseismic creep on the subduction interface promoted by the subduction of ridges or fracture zones (Saillard et al., 2017). Henry et al. (2014) showed that main parameter explaining coastal uplift is small-scale heterogeneities of the subducting plate as aseismic ridges. The magnitude and rate of coastal uplifts in fore-arcs do not appear correlated with the main geodynamics parameters. Thus we interpret the coastal uplift of the fore-arc at La Désirade to be related to the subduction of the Tiburon aseismic ridge. We propose that fore-arc uplift at the latitude of the Guadeloupe might reflect a change in frictional properties along the subduction 
interface persisting over a million year related to the subduction of the Tiburon ridge. In addition, it is

492 to note that subduction of aseismic ridges may also lead to fore-arc subsidence interrupted by rapid 493 uplift episodes (Clift and Vanucchi, 2004; Vannucchi et al., 2013). This is in accordance with the long494 term subsidence of the fore-arc at the latitude of the Guadeloupe archipelago, that is related to 495 extensional tectonics in the fore-arc and that was interrupted by at least two major uplift episodes: 496 one in late Pliocene and one in Calabrian times (Münch et al., 2014; De Min et al., 2015). The latter 497 corresponds to the emersion of the A. palmata reef platform between 1.48-1.07 Ma in La Désirade and was also evidenced onshore and offshore throughout the archipelago (Cornée et al., 2012; Münch et al., 2013, 2014; De Min et al., 2015). Since 0.78-0.97 Ma (Sicilian), uplift went on at La Désirade but with low uplift rates despite its location close to the trench and the elevated slab dip $501\left(60^{\circ}\right)$. Indeed, these two parameters have been shown to correlate with higher uplift rates, especially in accretionary convergent margins (Henry et al., 2014). Higher uplift rates were also evidenced in neighboring Caribbean areas with either compressive (Barbados, Gomez et al., 2018) or transpressive (western Hispaniola and Puerto Rico, Mann et al., 1995) fore-arc tectonics but these areas correspond to different tectonic regime of the subduction zone, accretional frontal subduction for the southern Lesser Antilles and oblique subduction in Hispaniola. The low uplift rates we evidenced in La Désirade are coeval with the N-S extensional tectonics of fore-arc. Such low uplift may rather correspond to erosional convergent margins (Henry et al., 2014). This is also supported by the presence of both numerous trenchward dipping normal faults within the Karukéra spur and Cenozoic carbonate platform sediments down the slope and close to the prism (De Min et al., 2015). Thus we propose that both extensional tectonics and low uplift rates in the Guadeloupe fore-arc exemplify

512 the erosional character of the Lesser Antilles subduction zone since 1 Ma in its central part (Bangs et 513 al., 2003; Münch et al., 2014; De Min et al., 2015) although geologic and tectonic processes included 514 accretion to form a frontal prism during former history of the central Lesser Antilles subduction zone. 515 Such varying erosional vs accretional character along subduction zones has already been shown in 516 relation with the subduction of asperities in different places (e.g. Aleutian; Von Huene et al., 2012). 
517 We also evidenced a marked decrease of mean uplift rates after the emersion A. palmata reef

518 platform in La Désirade and a continuous decrease of uplift rates until Present-Day. The high 519 magnitude of the uplift of the platform and the higher uplift rates of the terraces were clearly coeval 520 with a Calabrian extensional tectonic episode, and both may be the surficial expression of the 521 subduction of the Tiburon ridge at the latitude of La Désirade. Bangs et al. (2003) showed that the 522 backstop was deformed by the subduction of the Tiburon ridge, allowing sediments of the 523 accretionnary prism to subduct. At Present-Day the Tiburon ridge is no longer located beneath La 524 Désirade, but beneath the northern tip of the Karukéra spur sensu lato (Fig. 15D). This highlights that 525 the major Calabrian uplift, with high uplift rates, was related to a transient event at the subduction 526 interface provoking deep (backstop; Bangs et al., 2003) and surficial deformations. The vicinity of the 527 trench may have enhanced the strong vertical motion (Henry et al., 2014). Later, the moderate uplifts cannot be directly related to this transient event and may have been controlled by various parameters of the subduction zone, e.g. the high deep slab dip, the extensional tectonics of the overriding plate and the erosional regime of the subduction.

At Present-Day the Lesser Antilles subduction zone is known to be moderately seismically active compared to other subduction zones in the world, showing (i) only few earthquakes with a magnitude greater than 7 along the megathrust (Ruiz et al., 2013) and (ii) most of the seismic activity clusters along the active volcanic arc within the Caribbean upper plate ( $<50 \mathrm{~km}$ depths) (Christeson et al., 2003; Evain et al., 1013; Laigle et al., 2013). Moreover, at the latitude of the Guadeloupe, supra-slab earthquakes with normal-faulting seismic activity above $50 \mathrm{~km}$ depth were recorded whereas deeper flat-thrust earthquakes were not observed (Laigle et al., 2013). These observations may be consistent with low seismic coupling (aseismic creep) at the subduction interface. Indeed, it 539 has been proposed that the subduction of aseismic ridges provides fluids that can lubricate the 540 subduction interface in turn promoting aseismic creep along the megathrust or enhancing small 541 earthquakes occurrence (Chlieh et al., 2008; Schlaphorst et al., 2016; Saillard et al., 2017). Fluids may 
542 also be responsible for high serpentinization of the supraslab mantle beneath the northern Lesser

543 Antilles arc as proposed by Gailler et al. (2017).

544

545

\section{Conclusion}

546 In La Désirade, four shorelines angles were identified between 0 and 90 asl. They are associated with

547 sediments deposited in shallow marine environment and coral reef depositional settings. The

548 deposits of the terraces rest unconformable on both the basement and the Pliocene to early

549 Pleistocene red algal and coral reef carbonate platform (Upper Plateaus) indicating a post-platform

550 deposition eastward tilt. Aragonite corals from the three lowest terraces provided U/Th ages

551 allowing to establish a new age model: Terrace $4(+10 \mathrm{~m})$ dates MIS 5e, Terrace $3(+36 \mathrm{~m})$ dates MIS

5529 , Terrace $2(+76 \mathrm{~m})$ is MIS 15 or MIS 17 , Terrace $1(+90 \mathrm{~m})$ dates in the MIS $17-25$ interval and the

553 coral reef platform dates in the MIS 31 - 49 interval. Integrating U/Th dating and corrections of paleo-

554 sea level and paleobathymetry of the studied platforms and terraces allow us to provide estimates of

555 the apparent uplift rate at different times since 1.5 Ma. During Early Calabrian (1.07-1.5 to 0.78-0.96

556 Ma interval) the Upper Plateaus recorded transient deformation accommodated by NW-SE and ENE-

557 WSW trending normal fault systems. The mean uplift rate was high, in the $0.84-2.00 \mathrm{~mm} / \mathrm{y}$ range.

558 Then, since late Calabrian to Present-Day, uplift rates decreased from $0.26 \mathrm{~mm} / \mathrm{y}$ at least to 0.008 to

$5590.07 \mathrm{~mm} / \mathrm{y}$. This decrease is peculiarly well documented since $310 \mathrm{ka}$. The large early Calabrian uplift

560 appears to be related to the influence of the subducting, $2 \mathrm{~km}$ high oceanic Tiburon Ridge which

561 reached the subduction interface below the northern Karukéra Spur near 1.5 Ma ago. Later, the ridge

562 entered deeper into the mantle and its influenced vanished. The decreasing uplift rates then are

563 related to other parameters of the subduction zone like the dip of the deep of the slab or the basal

564 erosion of the upper plate or the extensional reactivation of Cretaceous structures related to ancient

565 history of the basement.

566

567 


\section{Acknowledgments}

This study was funded by the French National INSU Programs DyETI and SYSTER, the European Interreg IIIB 'Caribbean Space' and FEDER (op.30-700) projects as well as by the Region Guadeloupe and the French ANR GAARANTI. B. Fraisse performed the RX diffraction analysis (Réseau de Rayons $\mathrm{X}$ et Gamma Z, Ressource technologique de I'Université de Montpellier), D. Delmas and C. Nevado are thanked for thin-sections (Géosciences Montpellier). K. Pedoja (Caen University) is thanked for improvement of the manuscript. P. Mann and D. Fernandez Blanco are thanked for their reviews.

\section{References}

1. Bangs, N.L., Christeson, G.L., and Shipley, T.H., 2003. Structure of the Lesser Antilles subduction zone backstop and its role in a large accretionnary system. Journal of Geophysical Research, 108, 2358.

2. Barnes, P.M. and Nicol, A., 2004. Formation of an active thrust triangle zone associated with structural inversion in a subduction settings, eastern New Zealand. Tectonics, 23, TC1015.

3. Battistini, R., F. Hinschberger, C. T. Hoang, and Petit, M., 1986. La basse Terrasse corallienne (Eémien) de la Guadeloupe : morphologie, datation 230Th/ 234U, néotectonique. Rev. géomorph. dyn., XXXV, 1-10. https://www.researchgate.net/publication/291766951_The_Pleistocene_Eemian_low_coral_terr ace_of_Guadeloupe_morphology_Th230U234_dating_neotectonics

4. Bouysse, P., and Westercamp, D., 1990. Subduction of Atlantic aseismic ridges and Late Cenozoic evolution of the Lesser Antilles island-arc. Tectonophysics, 175, p. 349, p. 357-355-380. 
600

601

602

603

604

605

606

607

608

609

610

611

612

613

614

615

616

617

618

619

5. Bouysse, P., Garrabé, F., Maubussin, T. and Andreieff, P. , 1993. Carte géologique du département de la Guadeloupe : Marie Galante et les îlets de Petite Terre) 1/50000, Service Géologique National edn., BRGM, Orléans, France.

6. BRGM, 2010. Evolution et dynamique du trait de côte de l'archipel guadeloupéen. BRGM/RP58750, Final Report, Orléans (F), 93pp.

7. Chappell, J., 1974. Geology of Coral Terraces, Huon Peninsula, New Guinea: A Study of Quaternary Tectonic Movements and Sea-Level Changes. Bulletin of the Geological Society of America, 85, 553-570.

8. Clift, P.D., and Vannucchi, P., 2004. Controls on tectonic accretion versus erosion in subduction zones: Implications for the origin and recycling of the continental crust. Reviews of Geophysics, 42, RG2001.

9. Chlieh, M., Avouac, J. P., Sieh, K., Natawidjaja, D. H., and Galetzka, J., 2008. Heterogeneous coupling of the Sumatran megathrust constrained by geodetic and paleogeodetic measurements. Journal of Geophysical Research: Solid Earth, 113(B5).

10. Christeson, G. L., Bangs, N. L., and Shipley, T. H., 2003. Deep structure of an island arc backstop, Lesser Antilles subduction zone. Journal of Geophysical Research: Solid Earth, 108(B7).

11. Collot, J.-Y. and Fisher, M.A., 1989. Formation of fore-arc basins by collison between seamounts and accretionary wedges: An example from the New Hebrides subduction zone. Geology, 17, 930-933. 
628

629

630

631

632

633

634

635

12. Cornée, J.J., Léticée, J.L., Münch, P., Quillévéré, F., Lebrun, J.F., Moissette, P., Braga, J.C., MelinteDobrinescu, M., De Min, L., Oudet, J. and Randrianasolo, A., 2012. Sedimentology, palaeoenvironments and biostratigraphy of the Pliocene-Pleistocene carbonate platform of Grande- Terre (Guadeloupe, Lesser Antilles fore-arc). Sedimentology, 59, 1426-1451.

13. Corsini, M., Lardeaux, J.M., Vérati, C., Voitus, E. and Balagne, M., 2011. Discovery of Lower Cretaceous synmetamorphic thrust tectonics in French Lesser Antilles (La Désirade Island, Guadeloupe): Implications for Caribbean geodynamics. Tectonics, 30, TC4005.

14. Creveling, J.R., Mitrovica, J.X., Hay, C.C., Austermann, J. and Kopp, R.E., 2015. Revisiting tectonic corrections applied to Pleistocene sea-level highstands. Quaternary Science Reviews, 111, 72-80.

15. DeMets, C., Jansma, P.E., Mattioli, G.S., Dixon, T.H., Farina, F., Bilham, R.G., Calais, E. and Mann, P., 2000. GPS geodetic constraints on Caribbean-North America plate motion. Geophysical Research Letters, 27, 437-440.

16. Delanghe, D., Bard, E., Hamelin, B., 2002. New TIMS constraints on the uranium-238 and uranium-234 in seawaters from the main ocean basins and the Mediterranean Sea. Marine Chemistry, 80, 79-93.

17. De Min L., Lebrun, J.F., Cornée, J.-J., Munch, P., Léticée J.-L., Quillévéré, F., Melinte-Dobrinescu, M., Randrianasolo A., Marcaillou, B. and Zami, F., 2015. Tectonic and sedimentary architecture of the Karukéra spur: A record of the Lesser Antilles fore-arc deformations since the Neogene. Marine Geology, 363, 15-37. 
657

658

659

660

661

662

663

664

665

666

667

668

669

18. Deng, J. and Sykes, L.R., 1995. Determination of Euler pole for contemporary relative motion of Caribbean and North American plates using slip vectors of interplate earthquakes. Tectonics, 14, $39-53$.

19. de Reynal de Saint Michel, A., 1966. Carte géologique de la France et notice explicative, département de la Guadeloupe, feuilles de St Martin, St Barthelemy et Tintamarre, Basse-Terre et les Saintes, Marie-Galante et La Désirade, scale 1/50,000, Ministère de I'Industrie, Paris.

20. Diaz de Neira, J.A., Braga, J.C., Mediato, J., Lasseur, E., Monthel, J., Hernaiz, P.P., Pérez-Cerdan, F., Lopera, E. and Thomas, A., 2015. Plio-Pleistocene paleogeography of the Llanura Costera del Caribe in eastern Hispaniola (Dominican Republic): interplay of geomorphic evolution and sedimentation. Sedimentary Geology, 325, 90-105.

21. Dixon, T.H., Farina, F., Demets, C., Jansma, P., Mann, P. and Calais, E., 1998. Relative motion between the Caribbean and North American Plates and related boundary zone deformation from a decade of GPS observations. Journal of Geophysical Research, 103, 15157-15182.

22. Dominguez, S., Lallemand, S., Malavieille, J. and von Huene, R., 1998. Upper plate deformation associated with seamount subduction. Tectonophysics, 293, 207-224.

23. Dominguez, S., Malavieille, J. and Lallemand, S.E., 2000. Deformation of accretionary wedges in response to seamount subduction: insights from sandbox experiments. Tectonics, 19, 182-196.

24. Evain, M., Galve, A., Charvis, P., Laigle, M., Kopp, H., Bécel, A., Weinzierl, W., Hirn, A., Flueh, E.R., Gallard, J. and the Lesser Antilles Thales scientific party, 2013. Structure of the Lesser Antilles 
670

671

672

673

674

675

676

677

678

679

680

681

682

683

684

685

686

687

688

689

690

691

692

693

694

695

subduction forearc and backstop from 3D seismic refraction tomography. Tectonophysics, 603, 55-67.

25. Feuillet, N., Manighetti, I., Tapponnier, P., and Jacques, E., 2002. Arc parallel extension and localization of volcanic complexes in Guadeloupe, Lesser Antilles. Journal of Geophysical Research: Solid Earth, 107, ETG 3-1-ETG 3-29.

26. Feuillet, N., Tapponnier, P., Manighetti, I., Villemant, B., and King, G.C.P., 2004. Differential uplift and tilt of Pleistocene reef platforms and Quaternary slip rate on the Morne-Piton normal fault (Guadeloupe, French West Indies). Journal of Geophysical Research: Solid Earth, 109, B2.

27. Fietzke, J., Liebetrau, V., Eisenhauer, A. and Dullo, W.-C., 2005. Determination of uranium isotope ratios by multi-static MIC-ICP-MS: method and implementation for precise U-and Th-series isotope measurements. Journal of Analytical Atomic Spectrometry, 20, 395-401.

28. Gailler, L.S., Mertelet, G., Thinon, I., Bouchot, V., Lebrun, J.-F. and Münch, P., 2013. Crustal structure of Guadeloupe islands and the Lesser Antilles Arc from a new gravity and magnetic synthesis. Bulletin de la Société Géologique de France, 184, 77-97.

29. Gailler, L., Arcay, D., Münch, P., Martelet, G., Thinon, I., and Lebrun, J.-F., 2017. Forearc structure in the Lesser Antilles inferred from depth to the Curie temperature and thermo-mechanical simulations. Tectonophysics, 706-707, 71-90.

30. Gomez, S., Bird, D. and Mann, P., 2018. Deep crustal structure and tectonic origin of the TobagoBarbados ridge. Interpretation, 6, T471-T484. 
707

708

709

710

711

712

713

714

715

716

717

718

719

720

31. Gutscher, M.A., Kukowski, N., Malavieille, J. and Lallemand, S.E., 1998. Episodic imbricate thrusting and underthrusting; Analog experiment and mechanical analysis applied to Alaskan accretionary wedge. Journal of Geophysical Research: Solid Earth, 103, 10161-10176.

32. Henry, H., Regard, V., Pedoja, K., Husson, L., Martinod, J., Witt, C. and Heuret, A., 2014. Upper Pleistocene uplifted shorelines as tracers of (local rather than global) subduction dynamics. Journal of Geodynamics 78, 8-20.

33. Jara-Munoz, J., Melnick, D. and Strecker, M. R., 2015. TerraceM: A MATLAB ${ }^{\circledR}$ tool to analyze marine and lacustrine terraces using high-resolution topography. Geosphere, 12, doi: 10.1130/GES01208.1.

34. Kopp, R. E., Simons, F. J., Mitrovica, J. X., Maloof, A. C. and Oppenheimer, M., 2009. Probabilistic assessment of sea level during the last interglacial stage. Nature 462, 863-867.

35. Laigle, M., Becel, A., de Voogd, B., Sachpazi, M., Bayrakci, G., Lebrun, J.-F., and Evain, M., 2013. Along-arc segmentation and interaction of subducting ridges with the Lesser Antilles subduction fore-arc crust revealed by MCS imaging. Tectonophysics, 603, 32-54.

36. Lajoie, K. R., 1986. Coastal Tectonics. Active tectonic. N. A. Press. Washington D, C, National Academic Press, 95-124.

37. Lallemand, S. E., 1995. High rates of arc consumption by subduction processes: some consequences. Geology, 23, 551-554. 
38. Lallemand, S.E., 1999. La subduction océanique. Overseas Publishers Association, Gordon and Breach Science Publishers, London, 194 p.

39. Lardeaux, J.-M., Münch, P., Corsini, M., Cornée, J.-J., Verati, C., Lebrun, J.-F., Quillévéré, F., Melinte-Dobrinescu, M., Léticée, J.-L., Fietzke, J., Mazabraud, Y., Cordey, F. and Randrianasolo, A., 2013. La Désirade island (Guadeloupe, French West Indies): a key target for deciphering the role of reactivated tectonic structures in Lesser Antilles arc building. Bulletin de La Société Géologique de France, 184, 21-34.

40. Lasserre, G., 1961. La Guadeloupe: étude géographie (Vol. 2). Union française d'Impression, 2 vol Bordeaux, France, gr.in-8*, 1135 pp. https://www.abebooks.fr/servlet/BookDetailsPL?bi=5796175183\&searchurl=tn\%3Dla\%2Bguadel oupe\%2Betude\%2Bg\%25E9ographique\%26sortby\%3D17\%26an\%3Dguy\%2Blasserre

41. Laurencin, M., Marcaillou, B., Graindorge, D., Klingelhoefer, F., Lallemand, S., Laigle, M., \& Lebrun, J. F., 2017. The polyphased tectonic evolution of the Anegada Passage in the northern Lesser Antilles subduction zone. Tectonics, 36(5), 945-961.

42. Léticée, J. - L., 2008. Architecture d'une plateforme carbonatée insulaire plio - pleistocène en domaine de marge active (avant - arc des Petites Antilles, Guadeloupe): Chronostratigraphie, sédimentologie paléoenvironnements. Unpublished PhD Thesis, Pointe à Pitre, Université des Antilles et de la Guyane, 261 pp. http://www.diffusiontheses.fr/59450-these-de-leticee-jeanlen.html

43. Lisiecki, L. E. and Raymo, M. E., 2005. A Pliocene-Pleistocene stack of 57 globally distributed benthic $\delta 180$ records. Paleoceanography, 20.1.: PA1003. 
748

749

750

751

752

753

754

755

756

757

758

759

760

761

762

763

764

765

766

767

768

769

770

771

44. Mann, P., Taylor, F.W, Lawrence Edwards, R., and Teh-Lung Ku, 1995. Actively evolving microplate formation by oblique collision and sideways motion along strike-slip faults: An example from the northeastern Caribbean plate margin. Tectonophysics, 246, 1-69

45. McCann, W.R., and Sykes, L.R., 1984. Subduction of aseismic ridges beneath the Caribbean Plate: Implications for the tectonics and seismic potential of the northeastern Caribbean. Journal of Geophysical Research: Solid Earth, 89, 4493-4519.

46. Montaggioni, L. F. and Braithwaite, C. J., 2009. Quaternary Reefs in time and space. Developments in Marine Geology, 5, 1-21.

47. Münch, P., Lebrun, J. - F., Cornée, J. - J., Thinon, I., Guennoc, P., Marcaillou, B., Begot, J., Bertrand, G., Bes de Berc, S., Biscarrat, K., Claud, C., De Min, L., Fournier, F., Gailler, L. - S., Graindorge, D., Léticée, J. - L., Marié, L., Mazabraud, Y., Melinte Dobrinescu, M., Moissette, P., Quillévéré, F., Verati, C. and Randrianasolo, A., 2013. Pliocene to Pleistocene carbonate systems of the Guadeloupe archipelago, French Lesser Antilles: a land and sea study (the KaShallow project). Bulletin de la Société Géologique de France, 184, 99-110.

48. Münch, P., Cornée, J.-J., Lebrun, J.-F., Quillevere, F., Verati, C., Melinte-Dobrinescu, M., Demory, F., Smith, B., Jourdan, F., Lardeaux, J.-M., De Min, L., Leticée, J.-L. and Randrianasolo, A., 2014. Pliocene to Pleistocene vertical movements in the fore-arc of the Lesser Antilles subduction: insights from chronostratigraphy of shallow-water carbonate platforms (Guadeloupe archipelago). Journal of the Geological Society of London, 171, 329-341. 
772

773

774

775

776

777

778

779

780

781

782

783

784

785

786

787

788

789

790

791

792

793

794

795

796

797

49. Murray-Wallace, C. and Woodroffe, C., 2014. Quaternary sea level: a global perspective. Cambridge, Cambridge University Press.

50. Noda, A., 2016. Forearc basins: types, geometries, and relationships to subduction zone dynamics. GSA Bulletin, 128, 879-895.

51. Patriat, M., Pichot, T., Westbrook, G.K., Umber, M., Deville, E., Benard, F., Roest, W.R., Loubrieu, B. and Party, A.C., 2011. Evidence for Quaternary convergence across the North America-South America plate boundary zone, east of the Lesser Antilles. Geology, 39, 979-982.

52. Pedoja, K., L. Husson, V. Regard, P. R. Cobbold, E. Ostanciaux, M. E. Johnson, S. Kershaw, M. Saillard, J. Martinod, L. Furgerot, P. Weill and B. Delcaillau, 2011. Relative sea-level fall since the last interglacial stage: Are coasts uplifting worldwide? Earth-Science Reviews 108, 1-15.

53. Pedoja, K., L. Husson, M. E. Johnson, D. Melnick, C. Witt, S. Pochat, M. Nexer, B. Delcaillau, T. Pinegina, Y. Poprawski, C. Authemayou, M. Elliot, V. Regard and F. Garestier, 2014. Coastal staircase sequences reflecting sea-level oscillations and tectonic uplift during the Quaternary and Neogene. Earth-Science Reviews 132, 13-38.

54. Pichot, T., Patriat, M., Westbrook, G.K., Nalpas, T., Gutscher, M.A., Roest, W.R., Deville, E., Moulin, M., Aslanian, D. and Rabineau, M., 2012. The Cenozoic tectonostratigraphic evolution of the Barracuda Ridge and Tiburon Rise, at the western end of the North America-South America plate boundary zone. Marine Geology, 303-306, 154-171.

55. Pindell, J.L. and Kennan, L., 2009. Tectonic evolution of the Gulf of Mexico, Caribbean and northern South America in the mantle reference frame: an update. In: James, K.H., Lorente, M.A., 
and Pindell, J.L., eds., Origin and Evolution of the Caribbean Plate. Geological Society, Special

800

56. Pirazzoli, P. A., U. Radtke, W. S. Hantoro, C. Jouannic, C. T. Hoang, C. Causse and Best M. B., 1993. A one million-year-long sequence of marine terraces on Sumba Island, Indonesia. Marine

804 Geology 109, 221-236.

57. Rohling, E.J., Foster, G.L., Grant, K.M., Marino, G., Roberts, A.P., Tamisiea, M.E. and Williams, F., 2014. Sea-level and deep-sea-temperature variability over the past 5.3 million years. Nature, 508 ,

808

58. Ruiz, M., Galve, A., Monfret, T., Sapin, M., Charvis, P., Laigle, M., Evain, M ., Hirn, A., Flueh, J., Diaz, J., Lebrun J.F, and the Lesser AntillesThales scientific party, 2013. Seismic activity offshore Martinique and Dominica islands (Central Lesser Antilles subduction zone) from temporary onshore and offshore seismic networks. Tectonophysics, 603, 68-78.

813

59. Saillard, M., Audin, L., Rousset, B., Avouac, J. P., Chlieh, M., Hall, S. R., Husson, L. and Farber, D. L., 2017. From the seismic cycle to long-term deformation: linking seismic coupling and Quaternary coastal geomorphology along the Andean megathrust. Tectonics, 36, 241-256.

60. Saillard, M., S. R. Hall, L. Audin, D. L. Farber, G. Hérail, J. Martinod, V. Regard, R. C. Finkel and Bondoux, F.,2009. Non-steady long-term uplift rates and Pleistocene marine terrace 
61. Schlaphorst, D., Kendall, J.-M., Collier, J.S., Verdon, J.P., Blundy, J., Baptie, B., Latchman, J.L., Massin, F. and Bouin, M.-P., 2016. Water, oceanic fracture zones and the lubrication of subducting plate boundaries -insights from seismicity. Geophysical Journal International, 204, 1405-1420.

62. Shemenda, A.I., 1994. Subduction. Insights from physical modeling. London, Kluwer Academic Publishers, 215 p.

63. Schellmann, G., and Radtke, U., 2004. A revised morpho-and chronostratigraphy of the Late and Middle Pleistocene coral reef terraces on Southern Barbados (West Indies). Earth-Science Reviews, 64, 157-187.

64. Sieh, K., Ward, S. N., Natawidjaja, D., \& Suwargadi, B. W. (1999). Crustal deformation at the Sumatran subduction zone revealed by coral rings. Geophysical Research Letters, 26(20), 31413144.

65. Speed, R. C. and Cheng, H., 2004. Evolution of marine terraces and sea level in the last interglacial, Cave Hill, Barbados. Geological Society of America Bulletin 116, 219-232.

66. Taylor, F. W. and Mann, P. (1991). Late Quaternary folding of coral reef terraces, Barbados. Geology, 19, 103-106.

67. Tucker, M. E. and Wright, V. P., 1990. Diagenetic processes, products and environments. In: Carbonate sedimentology, Blackwell Publishing Ltd, Oxford, U.K., 314-364. doi: $10.1002 / 9781444314175 . c h 7$ 
860

861

862

863

864

865

866

867

868

869

870

871

872

873

874

68. Vannucchi, P., Sak, P.B., Morgan, J.P., Ohkushi, K.i., Ujiie, K., Scientists, t.I.E.S., 2013. Rapid pulses of uplift, subsidence, and subduction erosion offshore Central America: implications for building the rock record of convergent margins. Geology 41, 995-998.

69. Veron, J. E. N., 2000. Corals of the World, vol. 1-3. Australian Institute of Marine Science, Townsville, 404-405.

70. Villemant, B. and Feuillet, N., 2003. Dating open systems by the $238 \mathrm{U}-234 \mathrm{U}-230$ Th method: application to Quaternary reef terraces. Earth and Planetary Science Letters, 210, 105-118.

71. von Huene, R., Culotta, R., 1989. Tectonic erosion at the front of the Japan Trench convergent margin. Tectonophysics 160, 75-90.

72. von Huene, R. and Ranero, C.R., 2003. Subduction erosion and basal friction along the sedimentstarved convergent margin off Antofagasta, Chile. Journal of Geophysical Research: Solid Earth, 108.B2.

73. Von Huene, R., Miller, J. J., and Weinrebe, W.,2012. Subducting plate geology in three great earthquake ruptures of the western Alaska margin, Kodiak to Unimak. Geosphere,8, 628-644.

74. Westercamp, D., 1980. La Désirade, carte géologique à 1: 25000 et notice explicative. Service Géologique National, Bureau de Recherches Geologiques et Minières, Orléans, France. 
877 Fig. 1. Location of the studied area in the Lesser Antilles subduction zone (from Feuillet et al., 2002 878 and Münch et al., 2014).

Fig. 2. Main geological features of the Guadeloupe Archipelago, from Léticée (2008), Münch et al.

881

882

883

884

885

886

887

888

889

890

891

892

893

894

895

896

897

Fig. 3. A: Geological map of La Désirade, from Westercamp (1980), modified from new field investigations (this study); B: Lithostratigraphic succession, referred to the Grande Terre succession (Cornée et al., 2012; Münch et al., 2014); C: Cross section displaying the Present-day elevations of the investigated coral reef deposits.

Fig. 4. The Upper Plateaus. A: general view of the southern coast towards SW from Baie Mahault area; B: general view of Pointe Adrien, northern coast; C: partially dissolved Acropora palmata coral colonies (arrows; northeastern part of the Upper Plateaus).

Fig. 5. A: DNM with the marine terraces in the northeastern part of La Désirade; B: DNM with marine terraces in southern part of La Désirade; C: topographic profiles with location of the paleoshorelines surfaces; D: terminology of the different elements for the description of the terraces. 
Fig. 6. Terrace 1 (loc. Fig. 3). A: field view of the $90 \mathrm{~m}$ asl and $76 \mathrm{~m}$ asl terraces surface in the Pointe du Grand Abaque area; B: conglomeratic limestone with sandy calcareous matrix, red algae and benthic foraminifers; pebbles are encrusted by red algae (arrows).

902

Fig. 7. Terrace 2 (loc. Fig. 3). A: field view of the $+76 \mathrm{~m}$ terrace surface (arrows), Baie mahault area

904

905

906 (southern side of La Désirade); B: succession of terrace 2 at Route de La Montagne; C: field view of the succession; D: cross stratification (upper arrow) and hummocky cross stratification (lower arrow) in matrix supported conglomerates and microconglomeratic sandstones; E: aragonite Diploria coral colony; F: and G microscopic views of the aragonite walls of the corals (natural light).

Fig. 8. Terrace 3 (loc. Fig. 3). A: Terraces 3 and 4 at Cul Foncé; B: lithological succession in the terrace 3 at Cul Foncé; C: terrace 3 at Pointe Doublé; D: horizontal wavecut surface at $+36 \mathrm{~m}$, Roche du large. Same legend as Fig. 7.

Fig. 9. Marine deposits of Terrace 3, Cul Foncé (loc. Fig. 3). A: conglomerates with pebbles above the basement; B: 3D dunes in vertical accretion; C: parallel-bedding laminations with pebbly intervals (center) and cross-trough stratification (lower arrow); D: cross-stratification; E: aragonite massive coral colony DS 10-40; F: microscopic view of the coral colony (natural light). Same legend as Fig. 7.

Fig. 10. Terrace 4, Pointe Frégule (loc. Fig. 3). A: lithostratigraphic succession; B: low angle planar lamination; C: basal conglomerate; D: large Acropora palmata colonies (arrows); E: microscopic view of aragonite walls of the coral colonies (natural light). Hammer is $40 \mathrm{~cm}$ long. Same legend as Fig. 7. 
922 Fig. 11. Terrace 4, Pointe Fromager, northern coast of La Désirade (loc. Fig. 3).

923

924

925

926

927

928

929

930

931

932

933

934

935

936

937

938

939

940

941

942

943

Fig. 12. Terrace 4 (loc. Fig. 3). A: field view at Baie Mahault beach (near cemetery); B: Dated coral at Baie Mahault beach; C: microscopic view of the aragonite corals DS11-43 at Baie Mahault beach; D: Acropora palmata boudstone (arrows); E: massive Montastraea colony (hammer is $\mathrm{cm}$ long); F: terraces 3 and 4 at Pointe Mancenillier (loc. Fig. 3).

Fig. 13. Morphostratigraphy and apparent uplift rates at La Désirade. Marine isotopic stages from Lisiecki and Raymo (2005) and sea level estimates from Rohling et al. (2014).

Fig. 14. Ages and elevations of the marine terraces in the Guadeloupean archipelago. Guadeloupe: Battistini et al. (1986); Münch et al. (2013; 2014); Marie Galante: Feuillet et al. (2004); La Désirade: this work.

Fig. 15. A: Calabrian uplifts at La Désirade; B: distribution of vertical motions and location of the Tiburon Ridge below the Karukéra Spur in the Guadeloupe archipelago during Calabrian; C: Ionian to Recent uplift at La Désirade; D: distribution of vertical motions and location of the Tiburon Ridge below the Karukéra Spur in the Guadeloupe archipelago during Ionian to Recent. Reconstructions are based on Andreïeff et al., (1989), Bouysse and Westercamp (1990), Gailler et al. (2013), De Min (2014) and De Min et al. (2015). 
945

946 Table 1. Blank amounts of the isotopes used for U/Th dating.

947 Table 2. U-series results of La Désirade and Grande Terre fossil coral samples (all uncertainties quoted at $95 \%$ confidence level). For the correction of detrital ${ }^{230} \mathrm{Th}$ a ${ }^{230} \mathrm{Th} /{ }^{232} \mathrm{Th}$ activity ratio of $0.6 \pm$

949 0.2 has been applied. 


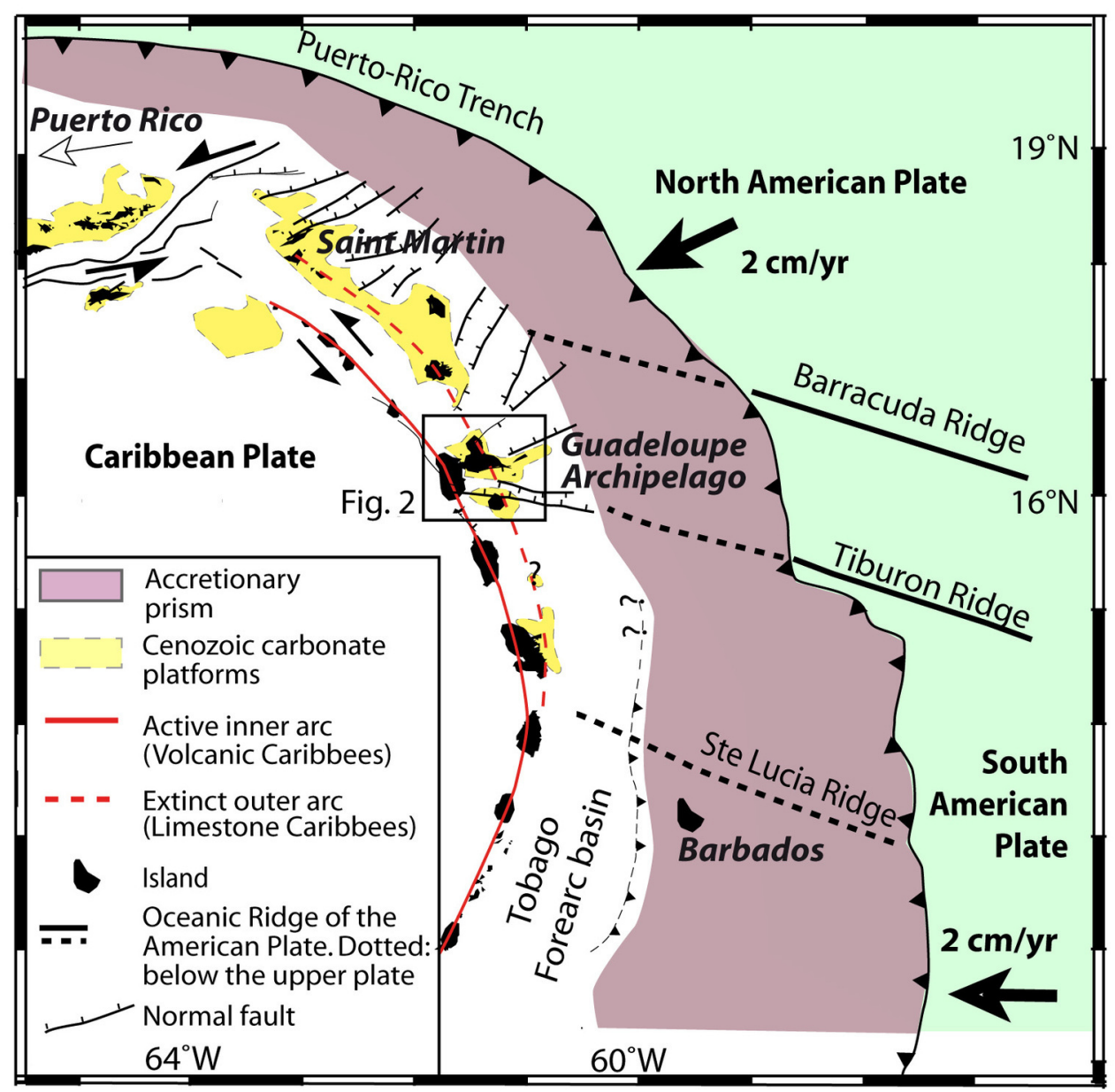

Fig. 1. Léticée et al. 
Léticée et al., Fig.3.

\section{METTRE AUTRES FIGS}

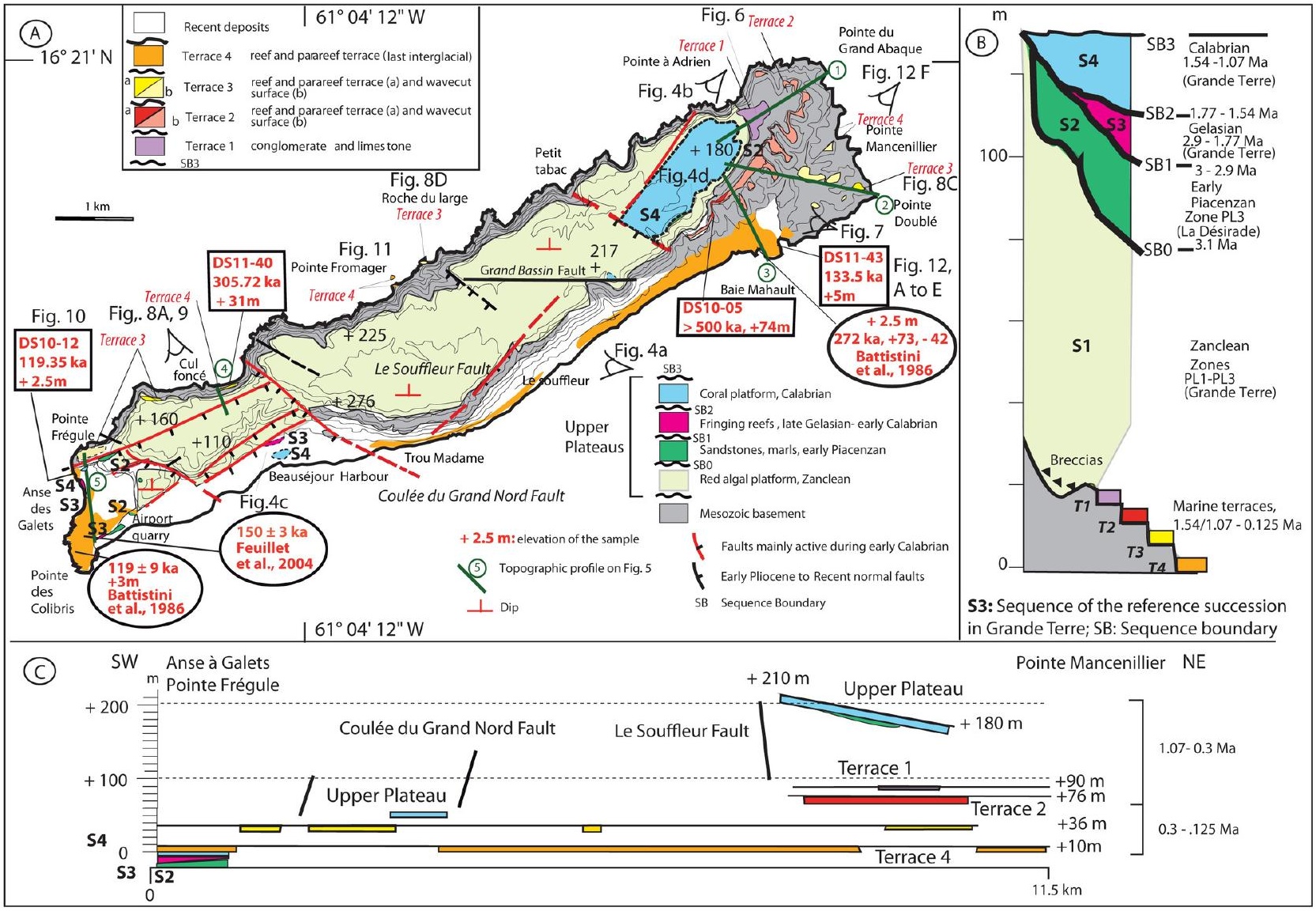



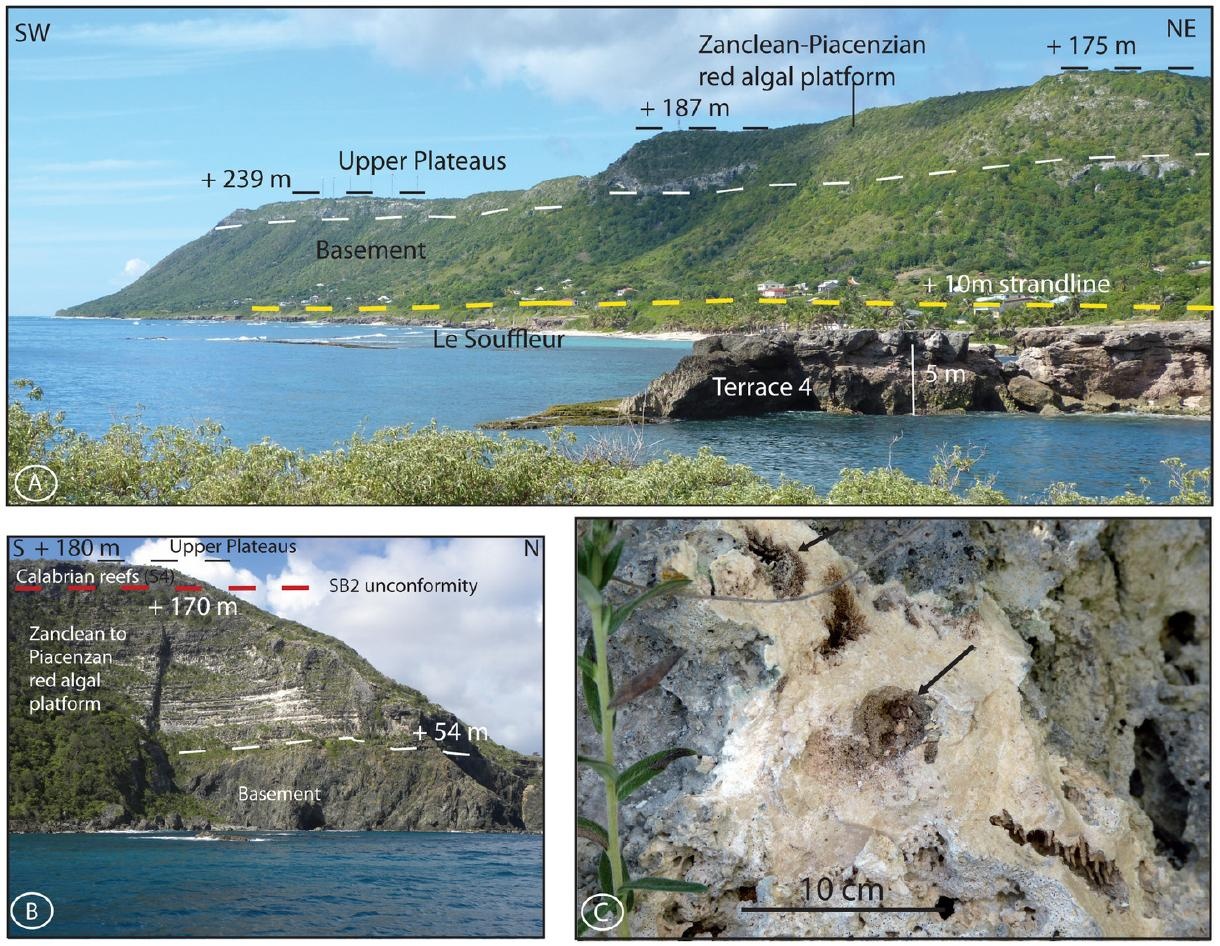

Léticée et al., Fig. 4 


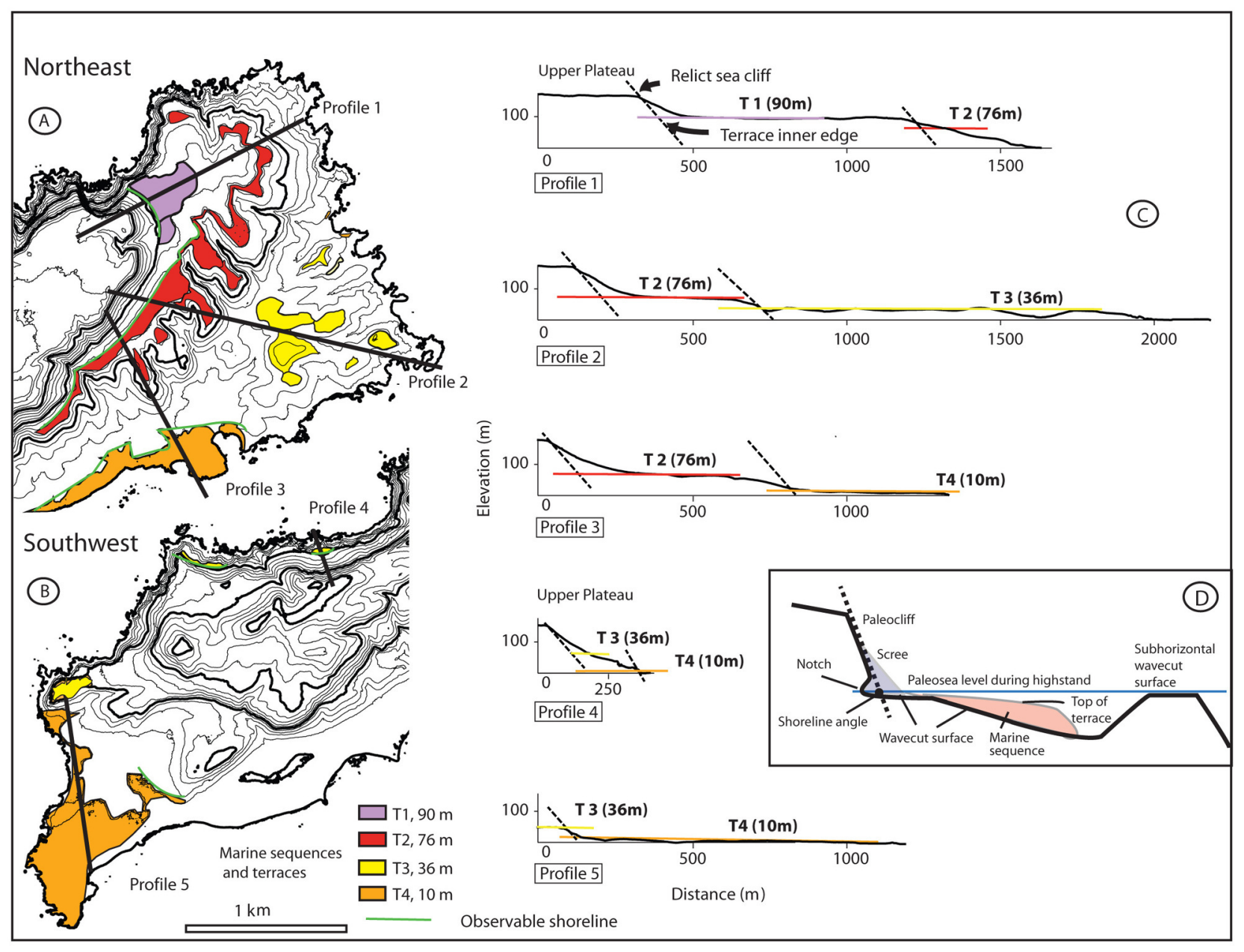




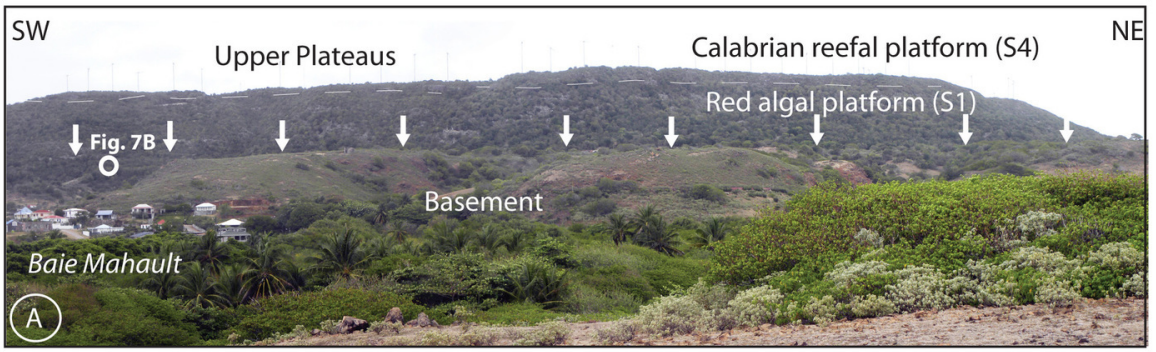

(B)

Route de La Montagne $16^{\circ} 19^{\prime} 58.1^{\prime \prime} \mathrm{N}$
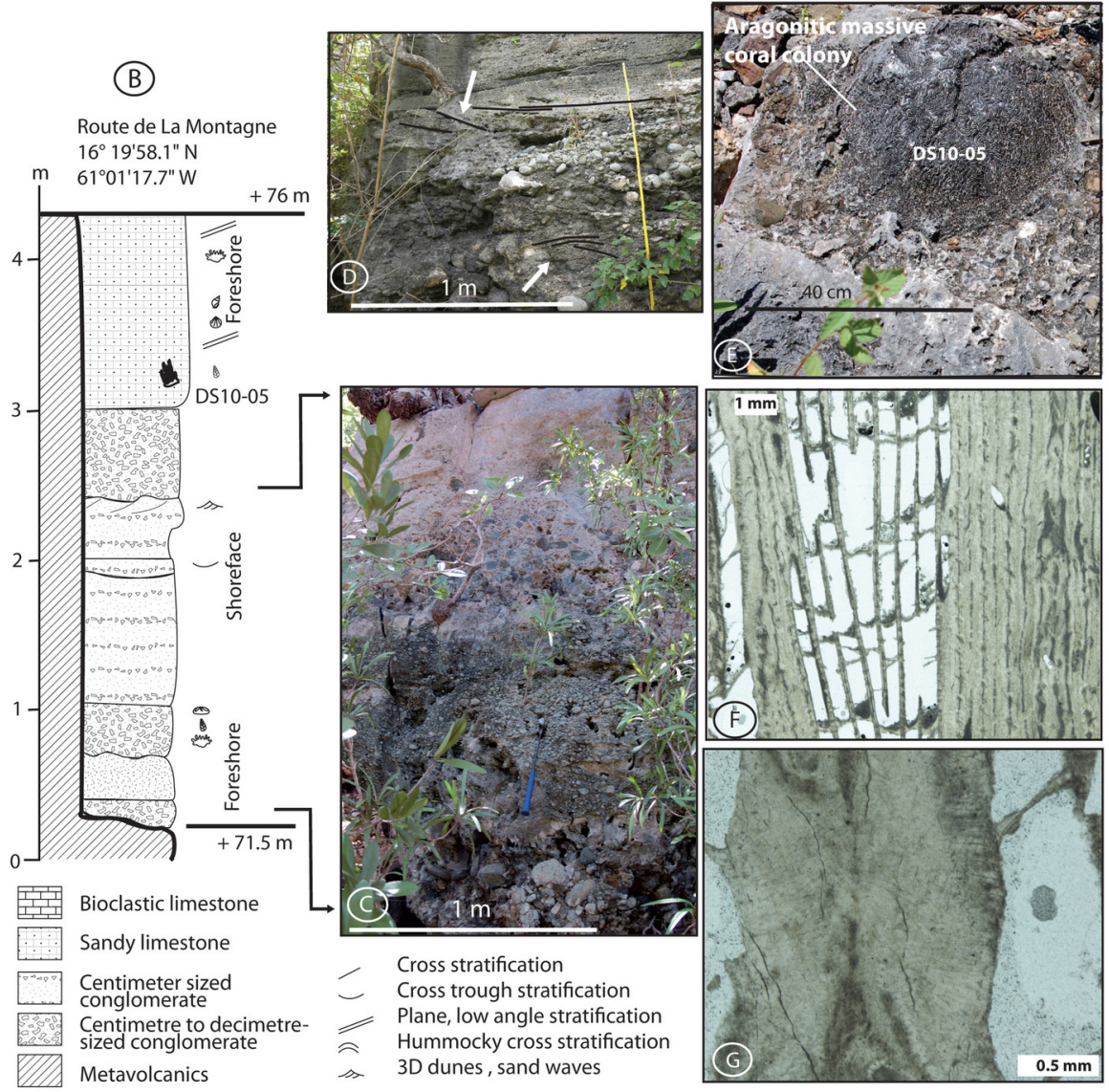

Bioclastic limestone

Sandy limestone

Centimeter sized conglomerate
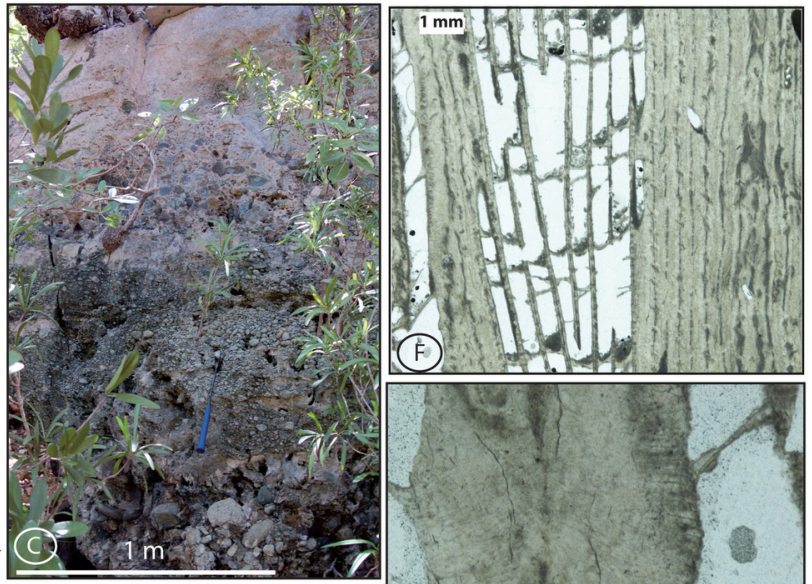

Centimetre to decimetresized conglomerate

Metavolcanics

Cross stratification

Cross trough stratification

- Plane, low angle stratification

$\approx$ Hummocky cross stratification

a 3D dunes, sand waves

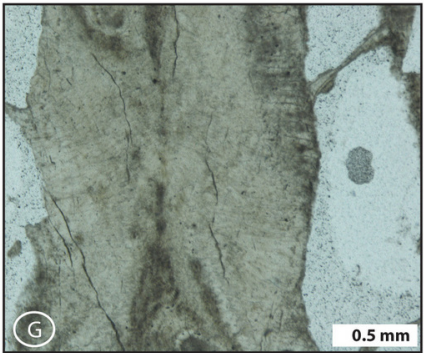

Coral Red algae Gastropod Bivalve Echinoid 

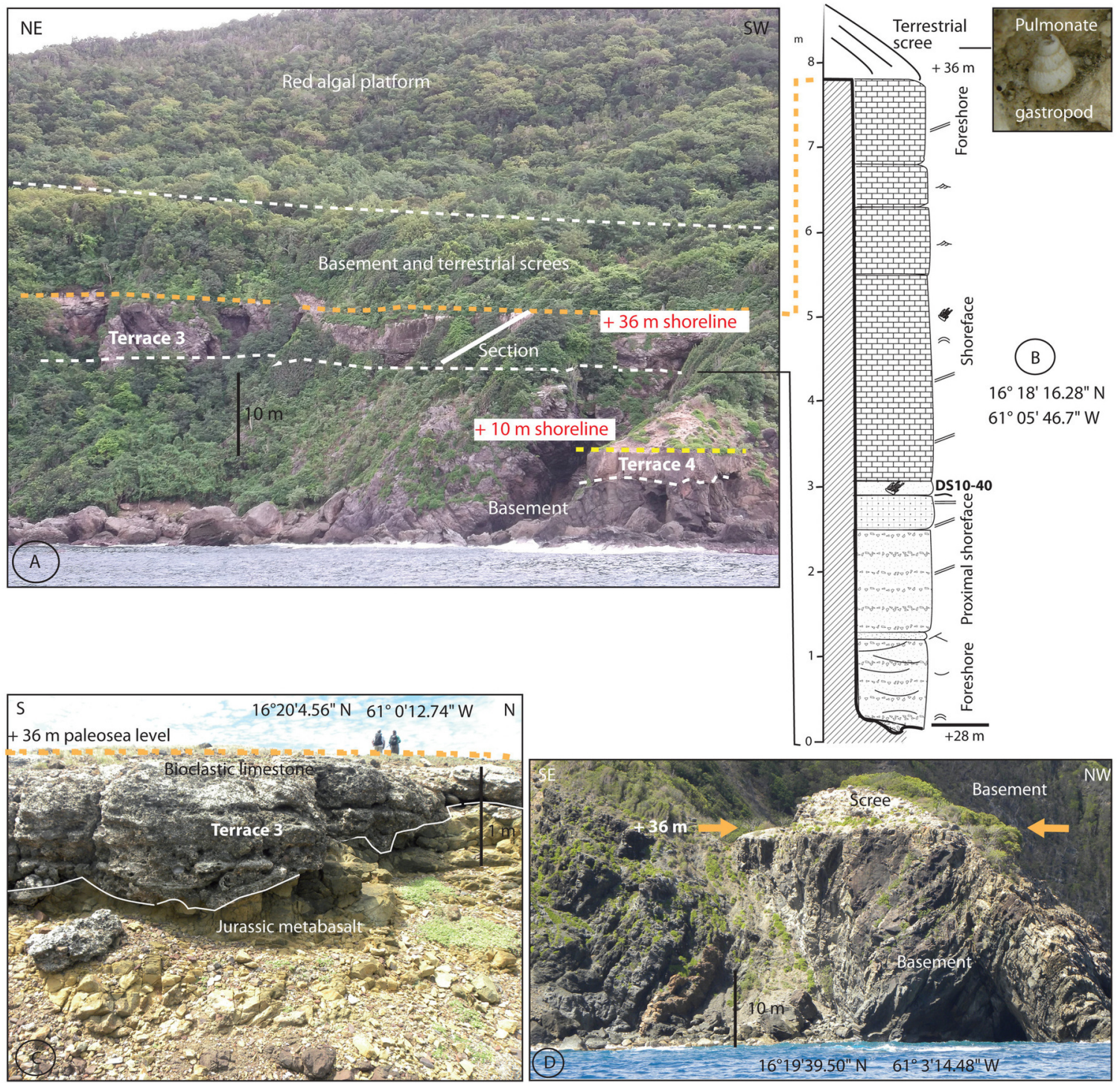

Léticée et al., Fig 8 


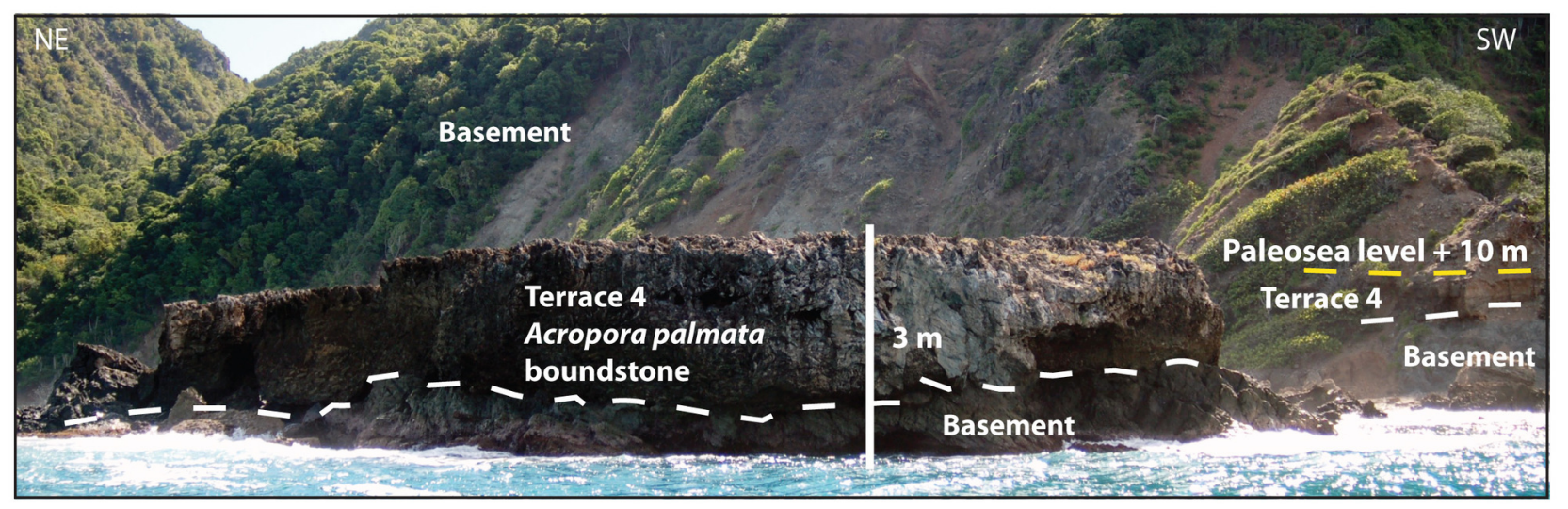

Léticée et al., fig. 11 


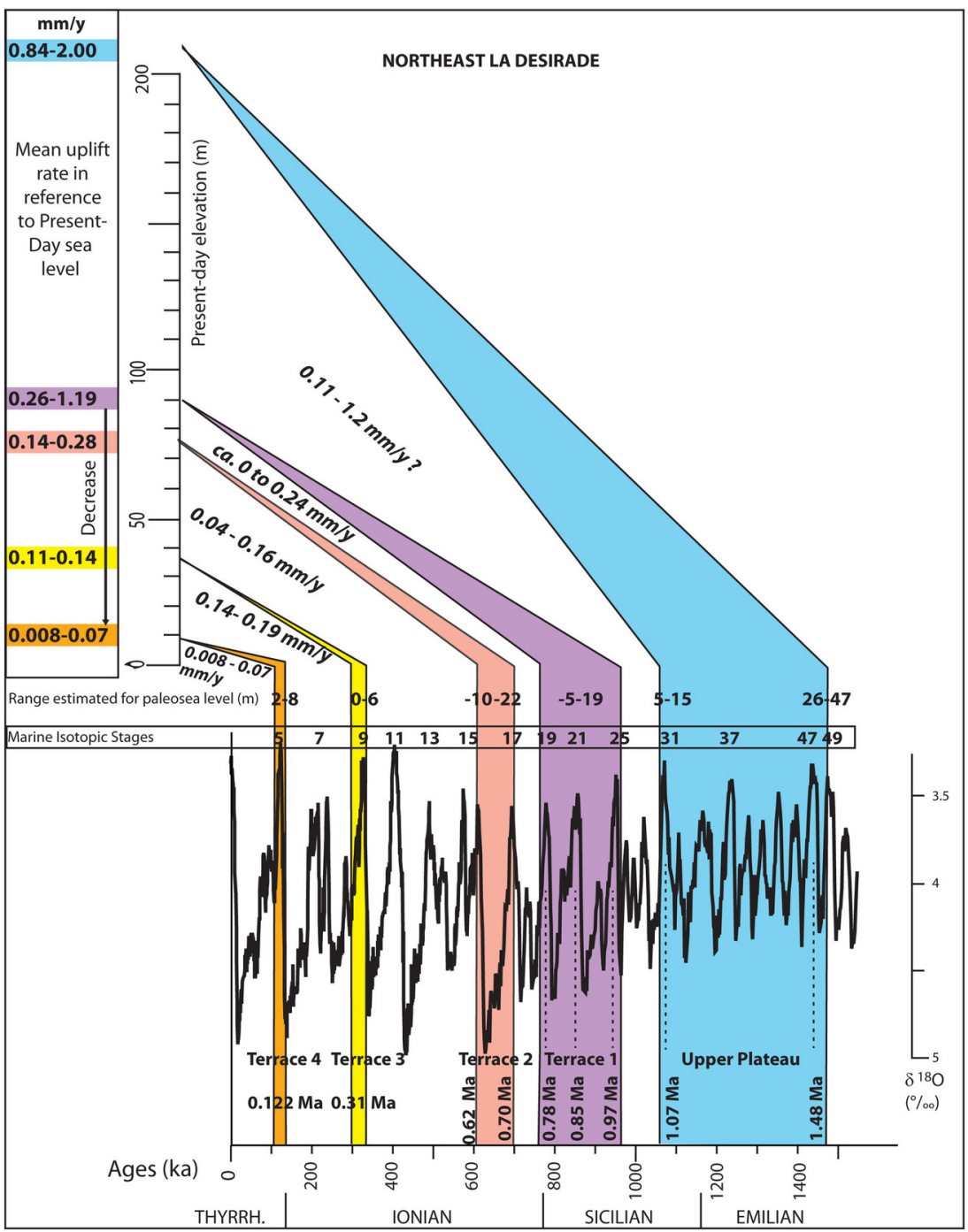




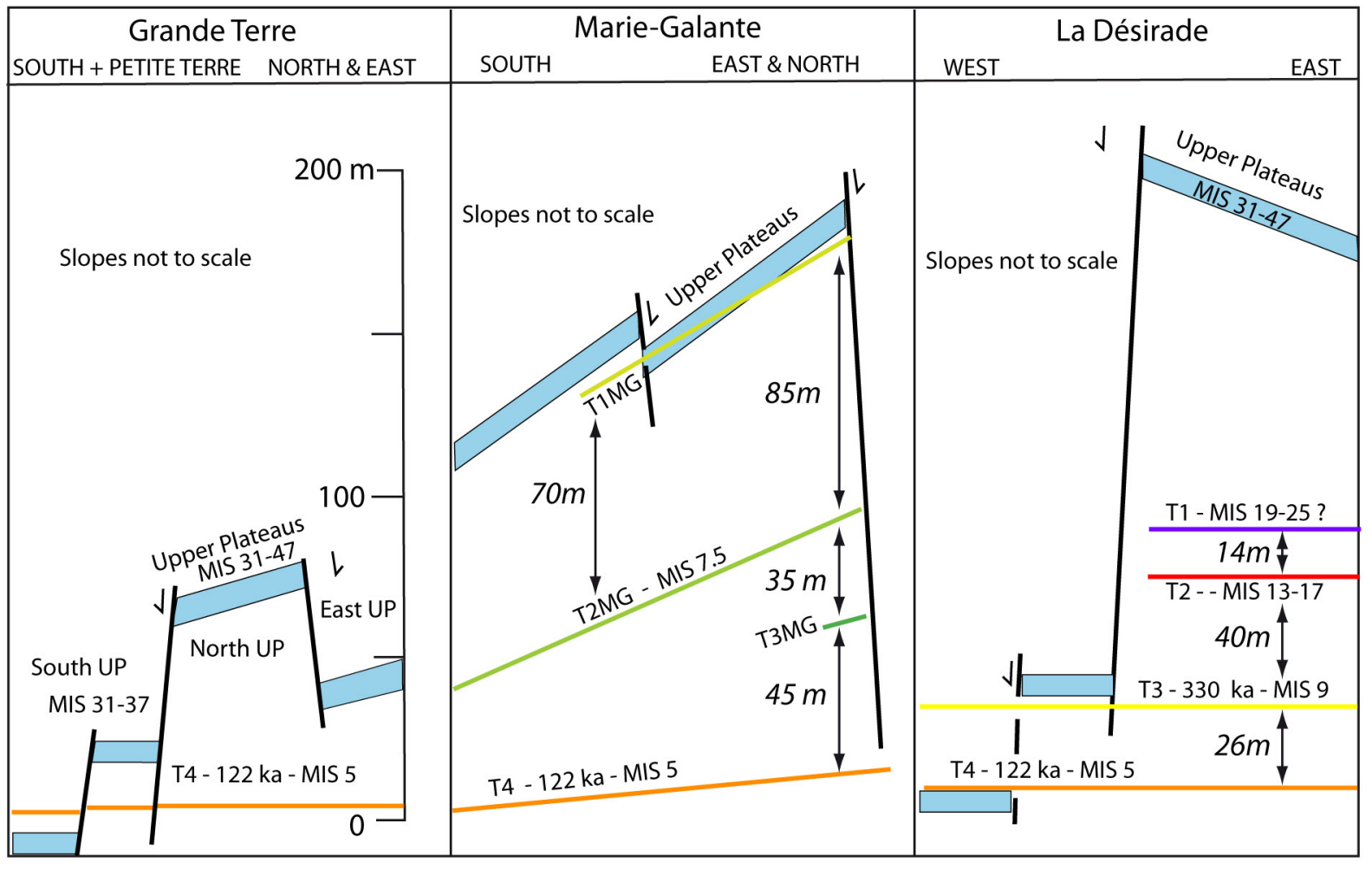



Léticée et al., Table 1

\begin{tabular}{|l|l|}
\hline isotope & blank in $\mathbf{g}$ \\
\hline${ }^{230} \mathrm{Th}$ & $(1.1 \pm 0.6) \mathrm{e}-16$ \\
\hline${ }^{232} \mathrm{Th}$ & $(4.2 \pm 2.1) \mathrm{e}-13$ \\
\hline${ }^{234} \mathrm{U}$ & $(7 \pm 4) \mathrm{e}-16$ \\
\hline${ }^{238} \mathrm{U}$ & $(9 \pm 5) \mathrm{e}-12$ \\
\hline
\end{tabular}




\begin{tabular}{|c|c|c|c|c|c|c|c|c|}
\hline Sample & $\begin{array}{l}\text { Age } \\
\text { [ka] }\end{array}$ & $\begin{array}{l}{ }^{238} \mathrm{U} \\
{[\mathrm{ppm}]}\end{array}$ & $\begin{array}{l}{ }^{232} \mathrm{Th} \\
{[\mathrm{ppb}]}\end{array}$ & $\begin{array}{l}{ }^{230} \mathrm{Th} /{ }^{238} \mathrm{U} \\
{[\mathrm{dpm} / \mathrm{dpm}]}\end{array}$ & $\begin{array}{l}{ }^{234} U / /^{238} U \\
{[\mathrm{dpm} / \mathrm{dpm}]}\end{array}$ & $\begin{array}{l}{ }^{230} \mathrm{Th} /{ }^{232} \mathrm{Th} \\
\text { [dpm/dpm] }\end{array}$ & $\begin{array}{c}\text { Location } \\
\text { of samples }\end{array}$ & Mineralogy \\
\hline \multicolumn{9}{|c|}{ La Désirade } \\
\hline DS 10-12a & $126.09 \pm 0.58$ & $2.3507 \pm 0.0014$ & $0.7963 \pm 0.0038$ & $0.77708 \pm 0.00085$ & $1.1159 \pm 0.0010$ & $7100.7 \pm 34.7$ & $\begin{array}{l}\text { Terrace 4, Pointe } \\
\text { Frégule, }+2.5 \mathrm{~m} \text {, }\end{array}$ & $\begin{array}{l}\text { Aragonite } 97 \%, \\
\text { Mg calcite 3\% }\end{array}$ \\
\hline DS 10-12b & $128.19 \pm 0.61$ & $2.3035 \pm 0.0013$ & $1.0197 \pm 0.0039$ & $0.78772 \pm 0.00106$ & $1.1204 \pm 0.0010$ & $5508.2 \pm 22.1$ & $\begin{array}{l}\text { Terrace } 4 \\
\text { Pointe Frégule, }+2.5 \mathrm{~m}\end{array}$ & $\begin{array}{l}\text { Aragonite } 97 \%, \\
\text { Mg calcite } 3 \%\end{array}$ \\
\hline DS 11-43 & $133.50 \pm 0.84$ & $2.1278 \pm 0.0018$ & $1.6745 \pm 0.0037$ & $0.79796 \pm 0.00100$ & $1.1118 \pm 0.0014$ & $3138.6 \pm 7.6$ & $\begin{array}{l}\text { Terrace } 4 \\
\text { Baie Mahault, + } 5 \mathrm{~m}\end{array}$ & $\begin{array}{l}\text { Aragonite 96\%, } \\
\text { Calcite } 4 \%\end{array}$ \\
\hline DS 11-40 & $305.72 \pm 5.96$ & $2.0724 \pm 0.0015$ & $0.6219 \pm 0.0039$ & $1.03372 \pm 0.00162$ & $1.0763 \pm 0.0014$ & $10661.8 \pm 67.7$ & $\begin{array}{l}\text { Terrace } 3 \\
\text { Cul Foncé, + } 31 \mathrm{~m}\end{array}$ & $\begin{array}{l}\text { Aragonite } 97 \%, \\
\text { Mg calcite } 3 \%\end{array}$ \\
\hline DS 10-05 & $>500$ & $2.0977 \pm 0.0010$ & $0.6625 \pm 0.0035$ & $1.04099 \pm 0.00125$ & $1.0221 \pm 0.0007$ & $10202.9 \pm 55.8$ & $\begin{array}{l}\text { Terrace 2, route de La } \\
\text { Montagne, }+74 \mathrm{~m}\end{array}$ & $\begin{array}{l}\text { Aragonite } 96 \% \text {, } \\
\text { Mg calcite } 4 \%\end{array}$ \\
\hline \multicolumn{9}{|c|}{ Grande Terre } \\
\hline A-EAU 5 & $125.01 \pm 0.44$ & $2.3303 \pm 0.0010$ & $1.7116 \pm 0.0036$ & $0.77213 \pm 0.00073$ & $1.1141 \pm 0.0007$ & $3254.0 \pm 7.3$ & $\begin{array}{l}\text { Terrace } 4 \\
\text { Anse à l'Eau, }+5 \mathrm{~m}\end{array}$ & $\begin{array}{l}\text { Aragonite } 97 \% \text {, } \\
\text { Mg calcite } 3 \%\end{array}$ \\
\hline
\end{tabular}

Léticée et al., Table 2 